\title{
ENTREVISTA A ELÍAS DÍAZ
}

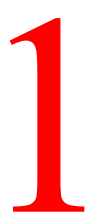

No vamos a entretenernos mucho en tu peripecia vital porque ya tienes publicada una autobiografía muy completa en la revista "Anthropos», pero nos interesaría particularmente que hicieras, para empezar, dos cosas no demasiado sencillas: una, periodificar tu propia vida, y otra, definirte como intelectual.

Está claro que no se me concede aquí espacio para suaves prólogos y lentas introducciones sino que se quiere entrar enseguida en profundidades, en definiciones de identidades personales: aceptémoslo si no queda más remedio.

Me veo más -dicho sea con alguna pretenciosidad- como un corredor de fondo, de una sola e interminable carrera, que como resultado de cambios drásticos en separadas o muy diversas etapas. Una carrera contra nadie, por lo demás; si acaso, pero sin rupturas, contra mí mismo. La hipotética periodización de esa continuidad, en espiral, de esa biografía intelectual, vendría más bien marcada por acontecimientos «externos», aunque siempre vividos, encajados y contestados desde esa propia, interna, evolución. Pero hay también, junto a ello, en mi biografía personal, y familiar, fechas inolvidables, buenas y malas (algunas están en ese resumen publicado en «Anthropos»), con incidencia importante, más o menos soterrada y en interrelación, a lo largo de esa «otra» biografía de carácter más intelectual.

Por facilitar y reorganizar el acceso a ese pasado -respondiendo así a la cuestión planteada- diferenciaría, simplificando mucho y entremezclando ambas dimensiones, varios principales «momentos»: uno, 1934-1956, años de Salamanca, de las guerra-s y posguerra-s hasta el final de mis estudios universitarios; dos, 1956-1965, Madrid, Bolonia, Friburgo, Munich, estudios de posgraduado y doctorado, iniciales publicaciones; tres, 1965-1975, primeros libros, 
últimos años del régimen franquista, actividad política y universitaria en la oposición, Pittsburgh y después Oviedo; y cuatro, 1975-1994, larga etapa hasta hoy, transición y consolidación de la democracia, buen tiempo de trabajo en la Universidad Autónoma de Madrid, cursos, clases, más libros, más (muchas más) conferencias, artículos, papeles, junto a otras colaboraciones no sé si más «prácticas» y/o públicas.

Todas estas tareas y resultados, de mayor o menor calidad, han sido un trabajo que no puedo no calificar de intelectual. ¿Qué otra cosa sería? Pero me es muy difícil (¡y más en esta primera respuesta!) «definirme como intelectual». Creo, de todos modos, que es algo que tiene que ver con ese oficio bien hecho, con respeto, seriedad, responsabilidad, compromiso, sentido crítico y otras cuantas cosas más. Para más detalles, confrontaciones e, incluso, definiciones reenviaría -esto es algo que precisamente suelen hacer los intelectuales- a uno de los últimos libros de Norberto Bobbio, Il dubbio e la scelta: intellettuali e potere nella societá contemporanea y también -¿por qué no?- a otro mío, Ética contra politica. Los intelectuales y el poder.

2. En tu pensamiento parece haber ciertos focos de inquietud bastante constantes. En tu bibliografía de los primeros años (la anterior a la publicación de Estado de Derecho y Sociedad Democrática de 1966) aparecen ya casi todos ellos: Teoría del Estado democrático, filosofía del Derecho de franca inclinación positivista y crítica del iusnaturalismo, opción por el socialismo y visión de un Marx no autocrático, reivindicación de la sociología del derecho, recuperación del pensamiento español del siglo XIX, etc. ¿Estás de acuerdo con ello o crees, por el contrario, haber experimentado alguna ruptura importante?

Estoy de acuerdo, a modo de descripción y explicación, con esa continuidad (en espiral, precisaba en el punto anterior), con esa evolución desde posiciones, perspectivas y metodologías asumidas entre los veinte y los treinta años respecto de buena parte de esos problemas centrales ya presentes entonces: no a la escolástica, no al exceso de formalismo, no a los reduccionismos aislacionistas y, en cambio, mucha mayor atención y consideración hacia las circunstancias históricas y sociales enjuiciadas desde una, que aspiraba y aspira a ser, razón crítica. En definitiva y abriéndose ya también con ello el campo político, libertad y democracia, autonomía privada y pública, personal y social, contra toda forma de dogmatismo, de opresión y de dictadura.

Unamuno y otros muchos han remarcado que toda obra intelectual, incluso todas las vidas reales, se mueven y se debaten siempre, en el fondo, en torno a una sola y única cuestión: yo no sería tan 
radical, o tan unívoco, pero confieso que tiendo a ver las cosas, y las gentes, preferentemente desde la perspectiva de la mediación, de la comunicación, de la interrelación, de la «totalidad» si se quiere (aunque sé que con este término complico la contestación). No, no ha habido rupturas espectaculares en mi «biografía intelectual» (ni personal): las rupturas, o las dudas y las ignorancias, las negaciones son más bien cosa de todos los días, de esa continuidad, de ese proceso evolutivo: y allí se van asumiendo como buenamente se puede.

3. Lo primero que sorprende de tu bibliografía es que se inicia con una crítica a lo que llamas «sustanciación de lo colectivo». En ella denuncias los peligros de atribuir propiedades éticas a los entes colectivos, como el Estado. Es algo en lo que coincides con los críticos de lo que hoy se denomina «comunitarismo». ¿Qué significado tenía ello para ti en 1961 ?

Imagino que, dadas las fechas, serían más bien, a la inversa, esos críticos actuales del «comunitarismo» los que en su caso coincidirían conmigo, y con aquellos otros en quienes, claro está, yo entonces me inspiraba. Mi crítica a la «sustanciación de lo colectivo» (años 1959-1961) era, sobre todo, una crítica a las filosofías políticas transpersonalistas que estaban detrás del Stato etico del fascismo italiano y de la racista Volksgemeinschaft del nazismo alemán.

Aparte de dejar claras las cuentas con ese negro pasado, mis alegatos querían ir también, en este país y en aquellos momentos, contra el mito místico y dogmático de la «España eterna», y su condena de la anti-España del exilio y la democracia, contra las irracionales «entificaciones» de la nación, de la patria, del «imperio» (hacia Dios), predicadas sobre todo en esos primeros decenios (pero en el fondo siempre operantes) por no pocos exégetas, teólogos y filósofos, del Estado totalitario y la dictadura. Se trataba, como puede verse, de una reivindicación básica de la persona individual, de su libertad, de su voluntad y de su racionalidad, pero buscando el mejor contexto social (democrático) en el que se pudieran hacer real para todos esas condiciones humanas, esas exigencias éticas.

4. Entre tus primeras publicaciones ya hay una crítica al iusnaturalismo por su sentido político conservado. ¿Cómo «naces» ya positivista en un medio ambiente tan unánimemente iusnaturalista? Porque es difícil recordar a nadie que en los años 50 se declarara positivista.

Yo no era, ni fui nunca, propiamente un positivista; o no era sólo, o del todo, positivista (exprésese como mejor parezca). Pero podía, 
sí, concordar con el positivismo desde mi convencida oposición al reaccionario iusnaturalismo teológico y teocrático de la época: es decir, como metodología eficazmente disolvente de aquella absolutización de las irracionalidades y arbitrariedades políticas, religiosas e ideológicas de signo más o menos tradicional que precisamente pretendían imponerse en nombre de una moral trascendente. Y, desde luego, también concordaba con él, con el positivismo (jurídico), al considerar el Derecho como Derecho positivo, al definirlo no por su justicia o injusticia - ¿es que acaso jueces, abogados y catedráticos no tomaban como Derecho el injusto Derecho franquista?- sino por su efectivo cumplimiento o reconocimiento social y político expresado en normas coercitivas aplicadas por los órganos pertinentes (en casi todos mis libros hay más explicaciones y matizaciones acerca de tal definición).

No confundía, pues, el Derecho que es con el «Derecho» que debe ser, pero tampoco aislaba ni escindía ambos mundos. Al contrario -y con esto supongo que ya no se me podría probablemente admitir dentro del positivismo- trataba siempre de comunicarlos y de dejar bien claro que la ética, el deber ser, la justicia también tenían mucho que ver con la razón. Así, en concreto, desde éstas, desde la razón y la ética, era posible la crítica y la oposición frente a aquel Derecho injusto de la dictadura.

Con esas limitaciones, y delimitaciones, tal impronta positivista debió -seguro- de venirme, o de incrementarse y fortalecerse, a través de la influencia de Tierno Galván y las lecturas por él recomendadas en aquella Salamanca de la segunda mitad de los años cincuenta: repásese por ejemplo la vieja colección «Estructura y Función» de Editorial Tecnos, serie por él entonces dirigida. En cualquier caso, recuerdo que yo disentía siempre de aquellos «tiernistas» que, de manera reductiva y cientificista, se protegían continuamente con aquella misma conocida invocación y advertencia: «yo no hago juicios de valor, sólo constato hechos». Es verdad que, con frecuencia, los hechos que allí se destacaban y constataban (europeos y demócratas) no coincidían para nada -y de ahí el carácter crítico de tal positivismo/sociologismo- con los hechos españoles de la época. Y también es verdad que Tierno, incluso en esa etapa de su biografía intelectual, no era sólo, ni principalmente, funcionalista. De todos modos, en esa resistencia al positivismo extremo también puedo reconocer la huella iusfilosófica de mi otro maestro de Salamanca, Joaquín Ruiz-Giménez, quien toleraba muy bien mis juveniles ataques a esas implicaciones conservadoras y reaccionarias del Derecho Natural.

5. Tu temprana vindicación de la sociología del derecho y tu constante llamamiento de entonces en favor de ella parece tener dos 
caras: una más puramente académica y científica (teórica, si quieres) y otra más decididamente práctica. ¿Es esto asi?

Como se desprende de todo lo anterior, la sociología, o la historia, yo las veo como ineludibles condiciones o básicas coordenadas (espacio-tiempo) en que se sitúa y hay que situar todo pensamiento, todo conocimiento: especialmente aquellos conocimientos que -como ocurre con los referentes al Derecho- pertenecen más al campo de las ciencias de la cultura, de las ciencias humanas o sociales (los rótulos son muy imperfectos), aunque también las ciencias de la naturaleza se beneficien -creo- del no olvido de sus connotaciones e implicaciones históricas y sociales. Pero, desde luego, la Ciencia del Derecho (legalidad) y la Filosofía del Derecho (legitimidad) se comprenden ellas mismas y, a la vez, se comunican mucho mejor entre sí a través de la importante mediación que ofrece la Sociología del Derecho (legitimación).

Junto a ese planteamiento, diríamos, más teórico, mi insistencia en la necesidad de investigaciones empíricas sociológico-jurídicas (aunque yo personalmente no las haya podido hacer) buscaba a la vez ese otro resultado «práctico»: conocer -empezando por nuestro país y por ese tiempo (también después)- cómo funciona realmente y para qué sirve un determinado sistema normativo incluyendo en ello el trabajo de las instituciones jurídico-políticas y de los profesionales del Derecho, especialmente de los jueces. Había que situarse más allá, pues, del formalismo de tantos juristas, despreocupados de consecuencias y antecedentes sociales, y más acá del iusnaturalismo de tantos filósofos que entonces ocultaban o distorsionaban, con la invocación de valores supremos y primeros principios, esa realidad social injusta del Derecho por ellos sacralizado como justo. Se trataba, entre otras cosas, de investigar fácticamente las causas, fuerzas e intereses que están detrás de unas $\mathrm{u}$ otras normas, sus efectos y consecuencias sociales $\mathrm{y}$, más en concreto, el funcionamiento -por ejemplo- de «la máquina de la Justicia» o de las diferentes, y algunas muy poderosas, profesiones jurídicas. Algo de esto es lo que yo tenía in mente cuando desde aquel tiempo hacía esa "vindicación de la sociología del derecho». Y en ello, desde luego, también me influiría después muy insistentemente el buen amigo y maestro Renato Treves a quién tanto debe la Sociología jurídica internacional en todos estos largos años y hasta su muerte en 1992.

6. Y enseguida aparecen ahi Unamuno, sobre todo, y también Giner de los Ríos. ¿Podrías darnos las razones de tan temprano interés en el pensamiento español? 
En el punto anterior era la sociología; en este lo es la historia. Y dentro de esta, como parte o sector de la entera historia real, estaría la historia de las ideas, de la cultura, del pensamiento. En relación con nuestra historia, de especial y predominante consideración incluso para ser después universal, mi propósito en aquellos años -además de informarme yo mismo- era ayudar a contrarrestar aquella absolutista y dogmática visión mística (pero con muy determinados intereses materiales detrás) de la denominada «España eterna»: la España tradicional, y tradicionalista, católica, ortodoxa, monolítica y excluyente que se había impuesto por la fuerza de las armas, reduciendo por el silencio o por la calumnia a todos los vencidos, vivos o muertos, y a sus predecesores intelectuales y políticos, como resultado de la devastadora guerra civil (incivil la llamaría enseguida el polémico y contradictorio liberal Miguel de Unamuno).

Se trataba pues de recuperar, en perspectiva plural, la España de los heterodoxos, la España ilustrada, liberal, democrática, socialista... Todo ello llevaría no poco tiempo y no pocos esfuerzos a historiadores y a otras muchas gentes que, en medio de enormes dificultades de todo tipo, intentaban volver a encontrar esta casi perdida memoria histórica, esas señas de identidad, esta otra parte decisiva de nuestra historia real. En tales tareas de entonces y de ahora recordaría aquí, entre otros, al gran amigo Manuel Tuñón de Lara. Por lo que a mí personalmente se refiere, en la Salamanca de entre los años cuarenta y cincuenta, Unamuno «alma y leyenda de la ciudad»-muerto, recuérdese, el 31 de diciembre de aquel bélico 1936- fue sin duda el más inmediato e inagotable incitante para esa puesta en cuestión de tantas cosas de nuestra historia y nuestra cultura. Luego, fruto ya de otras lecturas (Ortega) y otras experiencias, vendría la conexión con Giner y el mundo de la Institución Libre de Enseñanza, con quien toda esa heterodoxia contemporánea tenía algo que ver. (Va a ser difícil que en estas contestaciones no busque yo apoyo constante en cosas ya dichas en otros escritos míos: ahora, para ese Unamuno de la guerra incivil, y otras gentes e ideas de mis orígenes, en mi más reciente libro de este mismo 1994, Los viejos maestros: la reconstrucción de la razón; este subtítulo sugiere, por lo demás, que la historia o la sociología no son lo único ni lo último, pues también de ellas intenta siempre dar cuenta crítica la razón).

7. Las preguntas anteriores nos las han suscitado trabajos tuyos anteriores a 1966. En ese año aparece Estado de Derecho y Sociedad Democrática, un libro importante para toda una generación de juristas y de politicos. Después hablaremos de él con más detenimiento. Ahora nos gustaría que nos explicaras un poco la génesis intelectual y política, si es que la tuvo) del libro. 
Los inicios del que luego sería este mi primer libro podrían -creo- situarse, sobre la base siempre de cosas anteriores, entre 1959 y 1962, años de estudios, formales e informales, de doctorado y posdoctorado en las Universidades de Bolonia, Friburgo y Munich. Como contrapunto crítico de la filosofía política totalitaria del Führerstaat en el nazismo alemán y del Stato etico en el fascismo italiano, el Estado de Derecho se configuraba, también en mis ideas y en mis papeles de entonces, como coherente institucionalización jurídico-política de la democracia. Por supuesto que, a diferencia del confusionismo interesado que se intentaba crear en la España de la época, aquella era también la posición común y pacífica en la Europa democrática, y en otros países correlativos, así como en la ciencia y teoría social allí producida.

De modo totalmente consecuente con tal posición -y con ello entro ya en los orígenes cercanos de mi libro-, la «Comisión Internacional de Juristas» con sede en Ginebra publicó en 1962 su documentado informe sobre «El imperio de la ley en España» en el que, en efecto, se explicaban y detallaban los incontrovertibles hechos y argumentos que determinaban la no consideración del Estado franquista como un Estado de Derecho. En coincidencia con tal des-calificación, desde luego sin poder hacerla explícita sino ateniéndome más bien a los caracteres generales del mismo, tomando como base esas mismas razones y en similar orientación, escribí yo por entonces mi trabajo sobre «Teoría general del Estado de Derecho» que se publicaría en 1963. Pero, para esas fechas, el régimen del general ya no se contentaba -recuérdese- con declararse y enmascararse como «democracia (aunque) orgánica»; ahora, con Fraga Iribarne en el Ministerio de Información, se atrevía incluso a definirse -contra la opinión pública internacional y contra ese Informe de la Comisión de Juristas de Ginebra- como verdadero Estado de Derecho. Y así en 1964 se editaba en Madrid como «réplica» oficiosa, el increíble anti-informe titulado, de modo suficientemente expresivo «España, Estado de Derecho».

En este contexto político e intelectual -ya he hablado y escrito sobre ello en otras ocasiones-, esa cínica y prepotente suplantación de la verdad fue lo que me sirvió a mí de más inmediato estímulo para retomar y prolongar esas críticas y escritos anteriores sobre la cuestión y concluir la final redacción del que sería ese libro enseguida secuestrado por orden gubernativa: Estado de Derecho y sociedad democrática. Hoy parece una broma exagerada, pero en aquel momento hubo gentes, incluso no ajenas del todo al mundo jurídico, que me propusieron ponerle mejor como título el de «Panorama actual del Derecho y de la democracia»: se nos olvida, pero a tales extremos llegaba en España -año 1966- el desconocimiento de lo 
que significaba e implicaba definirse como Estado de Derecho. Y me temo que hay que seguir recordándolo hoy.

8. De esos años data también, si no estamos equivocados, tu opción intelectual en favor del pensamiento marxista. También hablaremos más de ello, pero quisiéramos ahora que describieras tu itinerario hacia el marxismo en aquella época.

Contar con el marxismo o, quizás mejor, con el conocimiento y reconocimiento de la obra de Marx, me parecía necesario para tratar de clarificar algo más las cosas en, junto a otros, dos principales problemas que iban siendo centrales en mis preocupaciones intelectuales y políticas: por un lado, el análisis crítico de las vías de profundización de la democracia liberal para una más efectiva realización de esos valores de libertad, igualdad y fraternidad (por decirlo con el tríptico tradicional), lo cual también implicaba cuestionar una economía (capitalista) basada en el absoluto control privado de los medios de producción y reproducción; por otro, más epistemológico, el programa coherente, desde una perspectiva de abierta totalidad, para una más rigurosa e interrelacionada indagación sobre esos componentes sociológicos e históricos del pensamiento, siempre con la determinación última por la razón crítica y en relación dialéctica (teoría y praxis) con la realidad.

Por supuesto que Marx no era el único que podía contribuir a todo ello, ni yo nunca lo vi así en exclusividad; pero también había que contar, y no poco, con él y había que decirlo y así se hizo -incluso por los que, para los ortodoxos, no eramos marxistas- en la España de la época. Había y hay marxistas (y marxianos y marxólogos) serios, críticos y abiertos, pero había también -y me temo que de manera latente y/o "amalgamada», siga habiendo- mucha dogmática y escolástica marxista que, junto con los desastres reales del comunismo, fue lo que acabó produciendo el cansancio e injusto y descrédito de tal filosofía. Por lo demás, algunos de los que estaban entre los más fideístas y acérrimos marxistas se pasaron después, pero con el mismo talante psicológico, al neoliberalismo y al más cientificista y fanático antimarxismo. Yo, de todos modos, para la ortodoxia marxista creo que fui siempre un mero reformista (no estaba con la «revolución»); un socialdemócrata que quería compatibilizar el socialismo y el marxismo con la democracia pluralista; en el mejor de los casos, un revisionista (como si no fuese todo, o casi todo, revisión y nada más que, crítica y creadora, revisión). Algo de todo esto estaba -creo- en esa «opción intelectual en favor del pensamiento marxista», en ese «itinerario hacia el marxismo», por el que se me indaga en este tan denso y sesudo cuestionario, verdadero examen de conciencia y de consciencia, o sea, de autoconciencia. 
9. Si te parece vamos a entrar en materias relacionadas con tu libro Estado de Derecho y Sociedad Democrática. Es un libro que nos plantea cuatro momentos teóricos muy definidos. Empecemos por el primero. Nos parece especialmente característico de tu pensamiento esa voluntad de integrar lo mejor de tradiciones no del todo compatibles. Tu posición ante el "Estado Liberal de Derecho» resulta muy ilustrativa. No se puede renunciar a él porque constituye un mínimo, o si lo prefieres una condición necesaria, pero no es lo que una sociedad democrática exige, o si lo prefieres no es una condición suficiente. ¿Crees que ese mensaje está todavía vigente, y en los mismos términos, o, por el contrario, introducirías en él algún matiz importante?

El mejor liberalismo y lo fundamental del Estado (liberal) de Derecho constituyen, así lo veía y lo veo yo, conquistas y valores irrenunciables también para nuestro tiempo: un «mínimo» básico imprescindible, la libertad como valor principal y como impulso eficaz para poner todo en acción, una «condición necesaria»-como se dice ahí- pero que algunos, no obstante, considerábamos, y consideramos, condición insuficiente; o, mejor, condición que es preciso complementar y materializar.

Ya sé, en parte lo haré, que todo esto se tiene que concretar mucho más. Advertiré ahora solamente que tal liberalismo ético y político no es para mí sinónimo, en modo alguno, de ningún individualismo de carácter asocial o antisocial, ni de su reducción «liberista» economicista, formaciones y deformaciones que, sin embargo, han prevalecido en el pasado y pugnan por volver a hacerlo hoy. El liberalismo es afirmación de la libertad como valor central: obvio, todo el mundo (liberal) lo admitirá; lo que ocurre -suelo anotar yo- es que, si es tan importante, tal libertad no puede ser sólo, o en amplia medida, de carácter formal sino real (también económico-social) y, además, no puede serlo sólo para algunos (minorías poderosas), sino que debe serlo para todos aquellos que componen la sociedad y, en definitivas cuentas, la humanidad. Precisamente es en ese proceso gradual y evolutivo (no maximalista ni perfeccionista) en el que se vinculan fuerte y profundamente el liberalismo progresista y el socialismo democrático.

Soy, creo, consciente de que en todas estas definiciones y relaciones, no digamos en las realizaciones, hay muchísima más dificultad, diversidad y complejidad de las que ahí, en esas líneas, van. Pero lo que no creo es que haya insalvable incompatibilidad y, por tanto, imposibilidad para seguir proponiendo como objetivo de nuestro tiempo esa necesaria progresión -que no ha hecho más que empezar- desde el originario, básico, Estado liberal hacia el que podemos 
denominar como Estado social y democrático de Derecho: sería tanto como negar que esa libertad individual puede ser real (material) y asequible (igualdad) a todos los demás. Aun con esa general coincidencia de enfoque y objetivos, no repetiría hoy -desde luego- todas y cada una de las palabras o ideas que están en ese libro de 1966. Espero que las diferencias y nuevas aportaciones estén ya apareciendo y sigan haciéndolo, como lo están ya -creo- en otras obras mías posteriores, a lo largo y ancho de estas laboriosas contestaciones sobre el pasado, presente y -al menos en prefiguración- también incluso el futuro de mis conclusiones políticas e intelectuales.

10. El segundo momento es el de la crítica al Estado totalitario de cuño fascista. Aquí nos parece que tu aportación a la formación de una conciencia intelectual antifascista es impagable. Porque no se trata solo de generar un movimiento sentimental, sitio de poner de manifiesto que los fundamentos teóricos, incluso "ontológicos», de la ideología fascista no se tienen en pie. Y sin embargo, ahí están otra vez. ¿Añadirías algo hoy a tu crítica de entonces?

Retomo aquí algunas de las que, sin propósitos exhaustivos, enumeraba en mi libro como principales características de los fascismos: totalitarismo, violencia y belicismo, capitalismo, concepciones transpersonalistas y nacionalistas, exaltación indiscriminada de lo irracional, elitismo y racismo. Desde ahí llegaba a una «fórmula» que, con todas las matizaciones que se necesiten introducir, pienso que no ocultaba ni distorsionaba lo fundamental: «Fascismo es -puede leerse allí- capitalismo más totalitarismo; es decir, capitalismo que organiza su defensa totalitariamente o, también, totalitarismo al servicio del capitalismo». En definitiva -proseguiría ahora- un Estado sin controles democráticos y al servicio prioritario del capital privado, de una omnipotente clase dirigente y de una economía totalmente dominada por un mixto poderoso de propietarios, empresarios, y muy altos jerarcas del partido único.

Hoy, en que asistimos a una absoluta glorificación acrítica, pretendidamente científica, del capitalismo -bajo eufemismos como economía de mercado y de la competitividad- me parece que es importante no guardar silencio, al menos para poder debatir, sobre aquella histórica, real, conexión. Todo se olvida. Era, quizás, otra forma de capitalismo pero era capitalismo. El anticapitalismo comunista no ha sido el único totalitarismo de este siglo. La búsqueda y conquista a toda costa, incluida la guerra, de mercados por países que, como Alemania e Italia, habían llegado tarde, por su tardía unidad nacional, al reparto colonial (o que, como España, acababan de perder su imperio y sus mercados), búsqueda disfrazada románticamente 
de demandas de «espacio vital» (Lebensraum), implicaba de manera muy fundamental la utilización y sacrificio total del pueblo en aras y beneficio muy privilegiado e inmediato de esos intereses privados de la gran burguesía y de las oligarquías económicas de dichos países. Pensemos, a escala española, quién sacó aquí el máximo provecho de la guerra civil. Y quién financiaba en todas partes a esos demagógicos partidos de extrema derecha.

Yo no creo que vuelvan ya esos viejos fascismos con sus mismos símbolos, gestos y demás parafernalia. Lo que sí hay son diversos tipos de neofascismo tecnocrático operando bajo mínimos democráticos. Pero estaremos, en todo caso, retrocediendo hacia aquellas u otras similares formas de barbarie a medida que consintamos y no nos resistamos a los odios nacionales, a la xenofobia, a las limpiezas étnicas, a capitalismos «científicamente indiscutibles» pase lo que pase en el mundo (hambre, destrucción, explotación), a fundamentalismos dogmáticos y fanatismos absolutamente irracionales, a corrupciones de la democracia y a violaciones del Estado de Derecho... ¡Queda, como se ve, muchísimo por hacer!

11. El tercer momento teórico de tu libro es una crítica muy contundente al Estado del Bienestar neocapitalista. Creemos advertir en esa crítica, como siempre, dos planos diferenciables. En primer lugar una mirada a la realidad española de los sesenta: un Welfare tecnocrático y sin libertades, es decir aquel desarrollismo del Opus Del, es una estafa que traiciona las condiciones «sine qua non» del Estado de Derecho. Nos gustaría saber si crees que esta crítica certera tiene alguna actualidad en la España de hoy. (Al segundo plano nos referimos en el punto siguiente).

Sí, se pueden y se deben diferenciar con rotunda claridad esos dos planos: por un lado, el desarrollismo económico español de los sesenta, hoy tan hipertrofiado y ensalzado, que se llevaba a cabo -aparte de con resultados estructurales muy deficientes- con despótica negación de las libertades, los derechos fundamentales y las exigencias básicas de todo Estado de Derecho; por otro, el Estado del Bienestar occidental con régimen político democrático y Estado de Derecho, al cual se aludirá en el apartado siguiente y que para nada debe aproximarse o confundirse con aquél. En el punto anterior ya se ha señalado que la economía del capitalismo, o alguna especie de él, no resulta de hecho incompatible con los regímenes políticos totalitarios y dictatoriales; eso es lo que también ocurrió, con caracteres propios, en aquellos años en nuestro país; los testimonios de opresión y represión son inapelables, se diga hoy lo que se quiera sobre las virtualidades liberalizadoras de tal capitalismo. 
En la España actual el distanciamiento o el olvido sin más de todo ese pasado y de la memoria histórica -bajo el alegato, justificado en sí mismo, de no volver a enfrentamientos fratricidas, de evitar rupturas definitivas y venganzas inacabables entre vencedores y vencidos- está en gran parte simplificando y distorsionando lo realmente acaecido en este país en aquellos tiempos postreros del franquismo que fueron como mínimo -pero hubo otros crímenes mayores- tiempos de ignominia, de persecución y humillación sin fin. Viene, así, a resultar hoy que en la explicación sobre los factores decisivos de la transición, tras la muerte del dictador, y sobre la construcción y consolidación de la democracia se pone con frecuencia mucho mayor énfasis en lo aportado por tal desarrollo económico tecnocrático que en lo efectivamente impulsado por la oposición política democrática. Ahora se quiere «capitalizar» lo que antes se negaba y se impedía con prepotente y cerrada obstinación, no sólo por los jerarcas autárquicos de la Falange sino también por las élites tecnocráticas del Opus Dei: que esos cambios infraestructurales (desarrollismo económico) y, después, superestructurales (sucesión en la Jefatura del Estado) fuesen ni subjetiva ni objetivamente orientados hacia una futura democracia: por fortuna disponemos de suficiente (in)oportuna documentación sobre todo ello. Acerca de esa suplantación, bastante difundida en nuestros días con mayor o menor sutileza o tosquedad, es sobre la que yo ironizaba críticamente en mi artículo Franco, artífice de la transición, incluido después en mi libro La transición a la democracia. Claves ideológicas (1976-1986), donde pueden encontrarse otros materiales sobre estas y otras correlativas cuestiones que, me parece, es importante no desconocer $u$ olvidar.

12. Pero a continuación -segundo plano- está lo que nos suscita las dudas más vehementes. Creemos poder afirmar que mantienes que el Estado del Bienestar adolece de insuficiencias intrínsecas simplemente por ser capitalista o neocapitalista, y esto es lo que plantea hoy todos los problemas. Por decirlo con toda claridad: podría decirse que tú mantienes que es demasiado poco, cuando estamos oyendo todos los días que ha ido demasiado lejos. ¿Cuál es hoy tu posición al respecto?

Hay que entender bien lo que significa que en amplia medida las insuficiencias intrínsecas del Estado del Bienestar provengan (pero para nada «simplemente») de que haya tenido que construirse con un sistema económico que, a pesar de todo, puede denominarse como capitalista o, mejor, neocapitalista. Significa -por lo menos así lo entendía y lo entiendo yo- que el control último y más decisivo de la economía (de la inversión, del excedente, de las plusvalías, en diferenciadas 
pero conectadas interpretaciones) está, en definitiva, en manos privadas, que por fuerza son minoritarias, hoy transnacionales y muy poderosas. Y ello a pesar de la existencia en ese Estado social de un muy dilatado sector público, no siempre -todo hay que decirlo- bien administrado o, incluso, bien orientado.

Conviene no olvidar, en todo caso, que por atender a un cierto tipo de muy importantes bienes sociales, de toda la colectividad, y a ineludibles necesidades básicas, especialmente de los no mejor situados, no es éste un sector que produzca ni pueda producir estrictos beneficios económicos; su rentabilidad es de otra índole, pero ello -es lógico- le veta competir en acumulación con el capital privado. Se subraya asimismo, aparte de ello, que otros mecanismos de compensación y reequilibrio en el funcionamiento interno del sistema conducen también con demasiada frecuencia a una, se califica, socialización pública de las pérdidas con correlativa apropiación privada de los beneficios. Difícil lograr, así, un sólido y progresivo sistema público de igual redistribución sobre la base, predominante, de una tan desigual producción privada. Estaba, por otro lado, el tema de la explotación del entonces «tercer mundo», suministrador de energía y mano de obra barata para la gran máquina occidental.

De todos modos, y a pesar de las críticas que lo que allí buscaban era justamente la corrección y superación de esos lados negativos (no se me negará, todavía hoy, el de la explotación de amplias zonas del mundo por esos intereses de las redes de agencias transnacionales), en mi libro había en lo fundamental un elogio y un válido reconocimiento del Estado social de Derecho, y también del Estado liberal. Pero se intentaba no inmovilizarlo con esas deficiencias, menos aun volver atrás como hace hoy el neoliberalismo conservador, sino más bien proponer reformas y transformaciones para avanzar hacia esa utopía (en el mejor sentido) que calificaba como Estado democrático de Derecho.

Yo no hablaba, claro está, en 1966 de «crisis fiscal del Estado» pero sí se preveía allí que, con esa contradictoria financiación, aquello no podía indefinidamente funcionar sin que surgiesen graves dificultades y problemas: de ahí la propuesta de ir más allá. Es verdad que entonces todos en la izquierda y yo también insistíamos más en la necesidad de aumentar y, fortalecer las coberturas de ese Estado social, en especial para los menos o nada protegidos. Hoy de ningún modo renunciaría a ello, sobre todo cuando se trata de necesidades básicas para todos (sanidad, educación, trabajo, seguridad social...), pero es verdad que -para esos objetivos- definiría la actual función del Estado mucho más desde un, digamos, intervencionismo selectivo y cualitativo que desde uno indiscriminado, improvisado y meramente cuantitativo que a veces hasta impide hacer bien lo que de 
modo ineludible se debe hacer. Más concreciones y puntualizaciones sobre esto pueden ir -creo- en el punto siguiente.

13. Y el cuarto momento de tu libro, el que nos parece más dificil teóricamente, pero también más definitorio de tu propuesta intelectual: la posibilidad de concebir un Estado de Derecho con morfología jurídico-política liberal y democrática, y basamento económico socialista. Aquí es donde todo parece confabularse contra tu punto de vista. Entonces arriesgaste la idea de que libertades, derechos, igualdad real y ausencia de explotación podrían tener un marco de realización institucional posible. Es lo que llamaste «Estado democrático de Derecho». ¿Podrías asumir hoy los fundamentos que te llevaron a proponerlo? ¿Sigues manteniendo hoy cosas en las que pareces haber insistido en escritos posteriores, tales como la «socialización de los medios de producción» o la «real liberación universal a través de la democracia»?

Necesito explicar, en relación con todo lo anterior, cómo entendería yo ese «basamento económico socialista» apto, en efecto, para articularse en un Estado democrático de Derecho. Advierto, de todos modos, que la cuestión no es única y exclusivamente económica. A diferencia del capitalismo que, como ya he señalado, implica control privado y oligárquico de la economía, para mí el socialismo era y es, entre otras cosas, control público democrático de esa economía. Pero en casi todos mis escritos insisto en no definir y entificar ambos términos, capitalismo y socialismo, como dos esencias absolutamente separadas, incomunicadas y cerradas en sí mismas, sino en verlas más bien como sectores diferentes y diferenciados de un amplio proceso histórico y social donde cada vez más las pacíficas, no pasivas, evoluciones muestran sus grandes ventajas sobre las violentas, fundamentalistas, revoluciones.

¿Tendría que pedir perdón, a propósito de todo esto, por seguir utilizando términos tan «obsoletos» como capitalismo (y no sólo economía de mercado) y socialismo (y no sólo política de progreso)? Espero que no, al menos entre gentes de izquierdas. Y aunque yo no sea un profesional de la economía, me atrevería según esto a sintetizar tal modelo socialista de organización, de producción y redistribución, en los tres siguientes niveles: economía privada (con prevalencia interna del mercado), economía pública social (con, entre otras, formas cooperativas y de autogestión) y economía pública estatal, para esos sectores que, por muy diferentes razones, no se pueden ni deben abandonar a la anarquía y/o tiranía del mercado. Economía mixta, se dirá: de acuerdo (todo es mixto en este mundo), pero lo decisivo es quién posee la hegemonía en tal compuesto sin negar la 
legitimidad de los demás porque ello no sería ni justo ni eficaz. Y, otra vez, ¿se me permitirá entonces reinsistir sobre la necesidad de organizar, regular, planificar toda esa complejidad?: su posibilidad está, por lo demás, en el art. 131 de la CE. Así, pues, socialismo democrático y Estado de Derecho: ésa era la propuesta.

No quiero eludir con lo anterior la pregunta que va ahí al final: aunque hoy preferiría expresarlo en términos como los ya referidos y aunque reconozco que algunas expresiones literales de aquellos viejos tiempos -«socialización, no estatalización, de los medios de producción»- necesiten ser mejoradas, precisamente mi insistencia, como digo, en articular todo ello en un Estado de Derecho evitaba -creo- cualquier riesgo de comunismo, o de estatalismo y totalitarismo. Siempre me encontré más identificado como reformista (pero hay reformas que transforman la realidad, otras quizás sólo la consolidan), como defensor para todos de libertades y derechos fundamentales, como un socialista democrático (otros me han calificado de socialista liberal y algunos -los más rojos- sólo de liberal). Desde luego, mi crítica a la ideología de la maldad de lo público nunca me ha llevado a la deificación o reificación de la institución estatal.

Unido a ello, otra cosa más y difícil -como, de manera cauta y me parece que bastante escéptica, señalan los autores del cuestionario- es demostrar teóricamente y, más aún (yo añadiría), realizar prácticamente tal compatibilidad entre, por un lado, esa economía del socialismo (democrático) y, por otro, su institucionalización en un Estado de Derecho. No creo, en cualquier caso, que todo haya sido mero voluntarismo. Como dice el propio Bobbio, quizás esta historia no esté apenas sino comenzando: para nada es el final, reductiva, conservadoramente, liberal. Por ello, en lo que sí estoy de acuerdo, dicho de un modo o de otro, es en el alegato a favor de esa «real liberación universal a través de la democracia». No me parece en modo alguno que sea ésta una mala meta: siempre abierta, es decir como utopía racional que pueda contribuir a transformar y superar críticamente las inhumanidades y corrupciones (también hay cosas buenas) de la realidad en el mundo actual. Como se ve, hay que seguir trabajando en este campo y en otros colindantes con él donde casi todo aparece hoy sometido a revisión.

14. Vamos a darnos un respiro filosófico-jurídico. Aunque no es ajeno a lo anterior (nos parece que en tu pensamiento nada es ajeno a lo anterior ni a lo posterior). $T u$ «sociología del Derecho Natural» es también un texto arquetípico. Una crítica a la deformación iusnaturalista de ciertas formas de dominación jurídica que parece una vindicación del positivismo jurídico. Y cuando creemos estar en los puros «hechos»o «normas» jurídicas, defiendes también una misteriosa 
mediación «hecho-valor» a partir de tu reivindicación de la sociología del Derecho. Ni con el iusnaturalismo ni con el positivismo. Nadie piadoso diría que esto es un "respiro» pero no nos importaría que nos dijeras como se puede pensar eso.

¡Gracias por el respiro! Lo necesitaba. E imagino que el hipotético lector también. ¡Bien vista por los sagaces encuestadores esa perspectiva de «totalización»: me congratulo por ello! Pero enseguida vuelvo a la carga, ya que no se me deja en paz. «Ni con el iusnaturalismo ni con el positivismo»: bueno, lo acepto; pero en esto me parece que no soy excesivamente original; son muchos (los mismos Hart o Bobbio, creo) quienes no se dejarían encasillar del todo en esos rótulos aunque quizás, como yo (y antes que yo), simpaticen mucho más con el segundo, el cual, por su parte, no agota tampoco todo lo que se debe decir del Derecho. Si quisiera meter al antijurídico Unamuno en estos berenjenales, podría añadir aquí que en lugar de esa «neutralidad» -ni con uno ni con otro- lo mío sería más bien la «alterutralidad», con uno y con otro, depende en qué aspectos, procurando después llegar a la síntesis, que implica negación y superación, de muchas de sus internas y externas contradicciones.

Las cosas claras (cuando, y en la medida en que pueden estarlo): yo sería positivista, pienso, por definir el Derecho como Derecho positivo, como sistema de legalidad, como sistema normativo producido y/o reconocido por un poder político y dotado de posibilidades de coacción institucionalizada; y por no definirlo como Derecho natural o ya como Derecho justo. Pero estaría, creo, mucho más cerca de algunos iusnaturalistas racionalistas (dando entrada a la sociología y a la historia) que de los positivistas extremos en cuanto a la posibilidad y necesidad de los juicios de valor, en cuanto a la importancia y racionalidad de las cuestiones de fundamentación, justificación y legitimidad del Derecho.

$\mathrm{Y}$ esa mediación entre los hechos normativos (legalidad), propios de la ciencia del Derecho, y los valores jurídicos (legitimidad/justicia), propios de la filosofía del Derecho, llevada a cabo a través también precisamente de las constataciones que sobre unos y otros incorpora la sociología del Derecho (legitimación), para nada me parece que pueda ser calificada de «misteriosa». Todos utilizamos y alegamos continuamente esas mediaciones sociales y lo hacemos con ese carácter intermedio, de mediación, no último ni definitivo pero muy importante y más tratándose de una creación social como es el Derecho. Lo que yo quería decir ahí es que desde hechos, comportamientos, actitudes, valoraciones que encuentran legitimación, es decir aceptación social, se puede favorecer y facilitar el acceso y la comunicación tanto a la legalidad como a la legitimidad: a la primera, 
como instancia crítica de las normas positivas desde una u otra efectividad social, incluso con efectos determinantes para su propia interna validez; a la segunda, como referencia o elemento de contraste con la más radical determinación personal de los juicios de valor. La sociología del Derecho constata, suministra, hechos sociales que encarnan valores sociales y ambos -con legitimación- sirven de relativa, siempre revisable, mediación entre las normas positivas (legalidad) y las concepciones éticas de la justicia. ¿Queda así aclarado el «misterio»?

15. Otro respiro, o presunto respiro. De pronto presentas la Minuta de un Testamento de Azcárate y no tardando mucho un libro luminoso: la Revisión de Unamuno. Recuperación del pensamiento español otra vez. Pero no sólo eso. La defensa de un liberalismo español, junto a la denuncia de sus insuficiencias. El krausismo, y Azcárate, aparecen como más coherentes: liberalismo ineludible pero insuficiente. Pero Unamuno es mucho más que eso. Suponemos que tu relación con la figura de Unamuno tiene muchas connotaciones de historia personal, pero también podríamos pensar que el desafio de sus contradicciones y agonías era algo especialmente estimulante para ti. ¿No es esto algo característico de tu actitud intelectual?

Los krausistas españoles, los institucionistas, Giner, Azcárate y sus derivaciones que, no se olvide, empezábamos por entonces a redescubrir, significaban (¿puedo hablar así?) el «momento» de la afirmación, el tiempo de la construcción; insuficiente la veía yo, mirando desde nuestra época, pero era una afirmación -valga la aparente redundanciatotalmente positiva: eran la razón, la modernidad, la libertad, la tolerancia, la ciencia, el liberalismo, Europa. Por su parte Unamuno, y otros del 98, representaban la negatividad -el motor de la dialéctica, sabíamos ya-, la irracionalidad alojada en lo racional, el conflicto, las contradicciones de esa liberal libertad, España por simplificar. A mí me interesaban las dos líneas (una más recta, otra más quebrada) y de ninguna de las dos he podido prescindir: y hacer síntesis tampoco era fácil, a veces ni siquiera posible, pero creo que era más fructífero intentarlo.

Unamuno -su recuerdo- estaba, de todos modos, más cercano en aquella universitaria y mesetaria Salamanca de los años cuarenta y cincuenta a la que ya he aludido aquí. Expresaba con fuerza, con pasión, las contradicciones e irracionalidades de la realidad, de cualquier realidad: era un pensamiento crítico y de oposición («contra esto y aquello») que no venía nada mal en la época, como antídoto y curación, ante tanto dogma e incondicional adhesión. Yo me identificaba 
bastante con él, porque además escribía muy bien, pero en ese libro del 68 ya ponía mis límites a sus excesos de (por ejemplo en la República) indiscriminada irracionalidad. Luego, mucho más tarde, he vuelto sobre el Unamuno final, el de la guerra incivil (julio a diciembre de 1936), y me he reconciliado en buena medida con él. Pero no me he olvidado nunca de institucionistas como Antonio Machado, Julián Besteiro o Fernando de los Ríos a quienes considero maestros míos y que en difíciles tiempos, con síntesis al menos parciales, también ayudaron ante todo a construir.

16. Y a continuación tenemos algo que resultó ser una provocación. El artículo sobre la filosofía marxista en España, publicado en Cuadernos para el Diálogo en diciembre de 1968, parece que fue usado como pretexto para enviarte al confinamiento de Villargordo. Experiencias personales inolvidables para ti, y también para muchos de nosotros (alguno de nosotros era el ayudante de aquel memorable examen en que los estudiantes olvidaron su interés por aprobar o no aprobar y se pusieron en pie a aplaudir para hacer un homenaje a sus profesores confinados), pero desde el punto de vista teórico ¿era sólo una provocación? ¿O era una propuesta de pensamiento marxista para España? ¿Describias o prescribias?

No, ese artículo no era sólo una descripción (¿cómo habría de serlo en aquellas circunstancias?) aunque pueda ser útil también para quienes quieran verlo exclusivamente así, pues había recopilada en él bastante información. Por otro lado, casi nunca una descripción es únicamente una descripción. Yo allí describía y prescribía a la vez, que es lo que todos, incluso los que no son conscientes de ello, suelen hacer. Pero desde luego que, aún con esa advertencia, me parece importante no confundir esos tres momentos que son describir, entender (en los dos sentidos) y justificar (prescribir). Se trataba, en definitiva, en aquellas páginas de dar difusión a autores, y obras, que en plurales perspectivas trabajaban sobre o desde la filosofía marxista en la España de esos años, animando -en eso consistía la prescripción- a los jóvenes a leer, discutir, escribir, aplicar (teoría-praxis) lo que libremente y sin anteojeras pudiera salir de allí.

Dicho artículo, por lo que supe después, resultó ser, en efecto, una «provocación» intolerable y así fue alegado en las alturas como uno de los motivos que dieron lugar a mi detención y confinamiento durante el «estado de excepción» de 1969. Pero al parecer también se hicieron valer allí otros méritos míos -nunca hay una sola causa- más relacionados estos con las tareas y acciones diarias en la Universidad, así como de otros profesores, Raúl Morodo, Gregorio Peces-Barba, Javier Muguerza, etc., también entonces confinados; 
muy en concreto, influyó también mi intervención en clase ante los estudiantes -con informadores presentes- al día siguiente de la muerte de Enrique Ruano, alumno y amigo mío, en manos de la policía política del franquismo. (Aprovecho, creo que con plena legitimidad, para llamar la atención sobre estas, u otras, circunstancias de la represión incluso en esas últimas fases del régimen -más tarde fueron ejecuciones y fusilamientos ante las protestas de todo el mundo civilizado- admitidas y aplicadas por el gobierno de los tecnócratas franquistas, supuestamente liberalizadores y falsamente predemocráticos, a que hacía antes referencia en el apartado once de estas mismas contestaciones).

17. El producto de un «fracaso» académico, un par de años después, es seguramente una de las obras más fértiles de tu trayectoria. Nos referimos a Sociología y Filosofía del Derecho, de 1971, que era la «Memoria» de una oposición truncada. Y, sin embargo, resultó ser una guía de lecturas importante. Ahora pasaremos a verla más despacio, pero no estaría demás que contaras algo de su elaboración.

Las páginas que utilicé como «Memoria» para esas frustradas oposiciones a la cátedra en 1966 -las primeras a las que yo me presentaba- y que luego, muy ampliadas y reformadas, dieron lugar en 1971 al libro Sociología y Filosofía del Derecho, condensaban en efecto buena parte de mis lecturas y conocimientos sobre «la materia» en esos años que van desde la segunda mitad de los cincuenta. Fue este para mí, en esa faceta académica, el tiempo de la «acumulación», de la integración y situación dentro de lo que se estaba haciendo en el mundo en filosofía jurídica: aún con las grandes limitaciones de la época en nuestro país, casi «estaba al día» de revistas, libros y monografías, aunque la verdad es que nunca fue esa, ni con mucho, ni principal preocupación.

Suelo yo decir, respecto de la configuración y evolución de todo «curriculum» docente e investigador, que después de esa fase de «acumulación» y recepción, viene (¿vino?) la de «producción», creación y (¿finalmente?) la de «distribución», divulgación, con la que me conformaría y casi justificaría actualmente. También es cierto, no obstante, que en la realidad todas esas fases se entrecruzan continuamente entre sí aunque en cada momento quizás prevalezca una u otra: no hay además acumulación, como es bien sabido, si no hay ya alguna forma de, al menos inicial, producción. Y claro está que uno, aunque no lo diga, no renuncia nunca a crear, recrear, cosas, palabras, ideas que puedan valer para uno mismo y/o para los demás. Quédense, pues, reconfortados los de mi edad y condición. 
En cualquier caso, lo que yo ahora a mis sesenta años estoy preparando y redactando, a diferencia de aquella casi juvenil y casi docta Sociología y Filosofía del Derecho, es precisamente un mucho más leve y breve Curso de Filosofía del Derecho, donde me considero fuera de toda posibilidad para intentar estar no ya al día, o al mes (de revistas y catálogos), sino ni siquiera al año o años, más recientes, respecto de toda la bibliografía aparecida y de las aportaciones hechas por los demás. No es orgullo, ni desprecio, ni -creo- irresponsabilidad: es sólo falta de tiempo (en el sentido más grave de la expresión) y necesidad de seleccionar cada vez más. Pero cuando leo y estudio algo nuevo en esa particular selección -me parece que ésta es todavía buena señal- siempre acabo aprendiendo e incorporando cosas, a veces tras la imprescindible crítica, para mi propio «proceso de producción».

18. En esa obra optas por una «concepción normativa del Derecho» que tiene fuertes connotaciones positivistas y se mueve en torno a la filosofía analitica. De hecho los tres autores que forman el núcleo de tu propuesta son Kelsen, Hart y Bobbio. Suponemos que eres consciente de que esa «troika» ha marcado el camino de la mayoría de tus discípulos. Y sin embargo no pareces estar del todo satisfecho de ello. ¿Es cierto?

Sigo considerando que Kelsen, Hart y Bobbio son, sin duda que con el añadido de Ross (como bien insiste Liborio Hierro), el núcleo fundamental de la filosofía jurídica del siglo XX; y, claro está, la base de esa «concepción normativa del Derecho» que se abre así a criterios empíricos de validez y, aquí invocando a Weber, también hacia la Sociología jurídica. En mi libro había -creo- eso, o parte de eso, por lo tanto no un positivismo formalista, pero se trataba en todo caso de una posición analítica no reductiva sino, insisto, necesariamente prolongada y completada por la sociología, la historia y el pensamiento crítico, por decirlo ahora de manera un tanto expeditiva.

Ése era, si se me permite la indicativa expresión, el gran plan, el programa que había ido resultando (no que me lo inventara yo): inagotable por lo demás, plural en perspectivas, siempre revisable y reformable. Pero, aún operando en esa válida línea general, ¿cómo se puede estar «del todo satisfecho» ni con uno mismo ni con los que los demandantes designan, en interpretación auténtica, como «discípulos»? Nunca se puede, ni se debe, (aparentar) estar del todo satisfecho, en especial ante y hacia discípulos tan sabios, orgullosos y (auto)exigentes. Pero que las críticas no me ahoguen los tan merecidos elogios: yo firmaría feliz -¡bueno, con algunas matizaciones y 
correcciones dentro!- la práctica totalidad de los libros y artículos publicados por ellos. ¡Ojalá los hubiera escrito yo! Nos han hecho avanzar a todos con el estudio de autores posteriores a aquellos, ya citados, grandes clásicos de nuestro siglo (ipara estos discípulos el XXI será también su siglo!) y dando entrada a temas y subtemas nuevos o apenas incoados en aquella concepción normativa y analítica del Derecho. Mi autocrítica a ellos -justa y necesaria- deriva, sobre todo, del esquema de crecimiento, muy desigual y fraccionado, con que se han propuesto (no) afrontar aquel plan general de trabajo y actuación. Seguiremos debatiendo fieramente sobre ello.

19. En ese libro también hay mucha insistencia en la demanda de una consideración sociológica del Derecho y en la necesidad de una asignatura en las Facultades. En esto lamentamos tener que decirte que has tenido mucho menos éxito, por no decir directamente que has fracasado. ¿A qué crees que se puede deber esto?

Me complace que los concienzudos entrevistadores constaten que, como ya he señalado en el apartado anterior, «en ese libro también hay mucha insistencia en la demanda de una consideración sociológica del Derecho»: o sea, por de pronto, analítica más sociología; y asimismo quise acoger la dimensión histórica de los problemas, con especial atención al contexto español, para su final calificación crítica. Pero, junto a tal reconocimiento, me complace aún muchísimo más que aquellos lamenten mi fracaso a la hora de lograr acoger e institucionalizar en nuestras Facultades esa asignatura de Sociología del Derecho: interpreto con ello -no se enfaden- que su pasivo lamento se convertirá en el futuro, y en cada oportuno momento, en activo apoyo a los proyectos de trabajos docentes e investigadores que nos conduzcan pronto a esa académica plena legalización. ¿O interpreto mal, una vez más?

¿A qué se debe -se me pregunta- tal retraso antisociológico en nuestros oficiales estudios jurídicos? Hace ventitantos años ya se hablaba de ello en mi libro. Pero resumo aquí de nuevo algunos de esos factores, sin volver a causas que antes, en el viejo régimen, eran también políticas de sentido reaccionario y ocultador: por un lado, el tradicional formalismo y autismo de tantos y tantos juristas que -por decirlo con un nuevo aforismosólo tratan de la realidad que va a pleitear: y lo hacen además de manera muy poco científica, más bien por aproximación e intuición; por otro, el frecuente desconocimiento y rechazo ( ¿«liberal-libertario»?) que no pocos sociólogos muestran ante el mundo del Derecho, de sus normas e instituciones, como algo simplistamente escindido de la sociedad civil, por tanto formas inertes que no merecen mayor sociológica atención; en un tiempo quizás 
también influyó el hecho de que gran parte de los sociólogos eran gentes procedentes de las Facultades de Derecho, y con esa titulación universitaria, pero que, aburridos, desencantados $\mathrm{y}$ «rebotados» de tales asuntos, por nada del mundo estaban dispuestos a volver ahora, como nuevos flamantes sociólogos, a los viejos contenidos, conceptos y esquemas, de lo jurídico, de su mala vida pasada; finalmente (es un decir, pues hay otros factores), la imposición -antes- de una iusfilosofía iusnaturalista y -ahora- neoformalista, que, divergentes en mil cuestiones y enfoques, coinciden sin embargo en su poca simpatía hacia la sociología, también ha sido causa de dicho retraso.

En los nuevos planes de estudio de las Facultades de Derecho ésta, la sociología jurídica, aparece al menos como asignatura optativa; esperemos que por esas vías de libre opción, contando asimismo con el trabajo y empuje de otros colectivos (de jueces, profesores o, por ejemplo, del Instituto Internacional de Sociología Jurídica, con sede en Oñati), se pueda pronto llegar a su definitiva incorporación a nuestra Universidad: o sea, con dotación y provisión de puestos docentes para gentes y equipos con preparación y entrenamiento en investigaciones empíricas y, a la vez, con adecuada formación jurídica, teórica y práctica.

20. Junto a El Derecho como lenguaje de Juan Ramón Capella, que es en sentido estricto el primer libro de filosofía analítica del Derecho escrito por un español, ha sido tu libro el que ha constituido la primera motivación hacia la filosofía analitica de toda una generación posterior. Y sin embargo ni Juan Ramón Capella ni tú parecéis defender hoy la filosofía analítica. ¿Puedes explicar esto?

Tal vez estemos, y esté también yo, utilizando aquí el rótulo «filosofía analítica» de manera no siempre bien precisa -acusará alguien- dando lugar a equívocos o ambigüedades que pudieran hacer confusa la necesaria claridad. Seamos conscientes de ello, introduzcamos prudentes cautelas y esperemos evitarlo así. Pero tampoco se trata de intentar formular en estas líneas el concepto exacto, exhaustivo e incontrovertible de lo que por filosofía analítica debamos entender: muchos y buenos libros hay sobre todo ello que nos podrán ayudar. Análisis es examen, estudio riguroso, incluso -reza el Diccionario de la Real Academia«distinción y separación de las partes de un todo hasta llegar a conocer sus principios o elementos». Hay que partir, pues, del análisis y hay que practicarlo en profundidad, evitando suplantaciones y distorsiones de la realidad y de la racionalidad.

Quisiera pensar que ésa era la filosofía analítica para la que generosamente 
los encuestadores encuentran motivación en mi libro, junto al del buen amigo y colega Juan Ramón Capella. El análisis y la analítica, con estudio serio y riguroso de los problemas, con lenguaje y métodos coherentes y comprensibles, implican eficaz disolución -así lo veía y lo veo yo- de míticas irracionalidades y arbitrariedades sin fin. Pero me parece, a su vez, que el análisis para ser creador necesita también de la síntesis, siempre abierta y en revisión, de la antítesis y de la interrelación (¿dialéctica?) de elementos y factores; que, por tanto, esa distinción y separación de las partes no debiera nunca conducir al fraccionamiento y al aislamiento de los diferentes materiales y componentes de la total realidad, ni obviar o negar el necesario juicio ético crítico sobre ella.

$\mathrm{Y}$, con alguna frecuencia, la filosofía analítica ha practicado y practica -pienso- ese reduccionismo, ese aislamiento formalista que incluso genera a veces una cierta nueva escolástica: como hubo, y hay, escolásticas tomistas e, incluso, marxistas. Ésas son, pues, aquí mis principales reservas y advertencias: la no escisión, en definitiva, con las condiciones históricas y sociológicas (y políticas), la no exclusión desde ahí de los racionales y críticos juicios de valor.

21. En 1973 aparece en forma de libro el grueso de tus investigaciones sobre el krausismo. Creemos que a pesar de tus constantes advertencias respecto de las insuficiencias del pensamiento krausista e institucionista, figuras como Giner Azcárate o Costa han dejado una huella en tus convicciones muy notable. Incluso tu conocida preferencia por un socialismo cercano al de Besteiro o Fernando de los Ríos denota esa huella. ¿Podrías explicitar en qué consiste?

Como ya señalé antes -en el punto sexto-, una de las acuciantes necesidades para la identidad personal y colectiva en aquellos años (así lo viví yo, concretamente, en los cincuenta y sesenta) fue la recuperación de ese pensamiento heterodoxo, ilustrado, liberal, democrático, socialista, que -proscrito y perseguido- en gran parte parecía perdido y olvidado tras la victoria de la España negra en la guerra civil. Y, ahí, para empezar con buen fundamento, un capítulo importante, imprescindible, era la Institución Libre de Enseñanza y sus precedentes en la recepción de la filosofía krausista e idealista alemana.

De ese racionalismo (armónico) y de ese liberalismo (progresista) derivarían después, en efecto, mis preferencias no exclusivistas por el socialismo democrático de Julián Besteiro y de Fernando de los Ríos. En ese contexto y trabajo común habrían de producirse, además de mi libro de 1973 sobre La filosofía social del krausismo español, las tesis doctorales de Francisco Laporta sobre Adolfo 
Posada y de Emilio Lamo y Virgilio Zapatero sobre los mencionados Besteiro y De los Ríos, así como de manera menos directa las de Manuel Núñez Encabo sobre Salés i Ferre y de Eusebio Fernández sobre marxismo y positivismo en el socialismo español. Todas ellas han sido después publicadas, con muy favorable influencia, si bien haya que reconocer que no adecuadamente continuadas para esa tarea de recuperación, contra el olvido y la ignorancia, pero que no es de casticista autoidentificación, por los discípulos comunes en el gremio iusfilosófico (algo, no obstante, comienza a cambiar de nuevo en este campo entre los más jóvenes), aunque sí con desigual fortuna por otros historiadores e investigadores. Yo también reenviaría a algunos capítulos de posteriores libros míos como Socialismo en España: El partido y el Estado, de 1982, o el de 1994, ya citado antes en el mencionado punto sexto de estas mismas contestaciones.

Para no reinsistir, ni siquiera de manera resumida, en lo ya dicho en tales escritos, sólo aludo ahora, a propósito de estas cuestiones, a dos aspectos que me siguen pareciendo de interés: uno se refiere, por separado, a la creciente consideración que está adquiriendo hoy la filosofía de Krause también entre los alemanes (aquí las investigaciones de Enrique M. Ureña y su equipo) y, a su vez, al estudio de las plurales manifestaciones en el pensamiento español contemporáneo (aquí las obras de José Luis Abellán y sus discípulos); otro remarcaría la importancia que precisamente para la España actual -en la que se dan muchas cosas positivas junto a también graves deficiencias, corrupciones y confusionespuede y debe tener un pensamiento como el de esos nuestros clásicos Julián Besteiro y Fernando de los Ríos, pero no solamente ellos, que propugnaron un socialismo democrático, un socialismo humanista basado justamente en la ciencia y en la ética, en la ciencia y en la conciencia.

22. Y luego están las Notas que se publicaron después como Pensamiento español en la era de Franco. Aquel fue un libro de gran éxito, pero parece un poco contradictorio. La denuncia de la represión y de los tiempos oscuros se compatibiliza en él con una defensa de lo que se hizo entonces con un criterio que alguien se atrevería a calificar de «benevolente» cuando menos. Dejando a un lado el excelente trabajo informativo que representa el libro, uno podría dudar de tanto afán de salvar cosas que no tendrían tanto valor objetivo. Es posible que eso se conecte con un afán muy tuyo pero que no se entiende muy fácilmente por vindicar el pensamiento español. ¿Te animarías a justificar esta especie de defensa de las cosas españolas? Porque no se te oculta que muchos no acaban de entenderla del todo. ¿Hay alguna aportación intelectual española de esos años que tú destacarías especialmente? 
Éste es quizás el libro mío que algunos han entendido peor, es decir más anacrónicamente: se escribió entre 1969-1973 y se publicó en 1974, es decir en la fase dura del final del franquismo. Hoy parece, y es, «benevolente» y tal vez excesivamente comprensivo hacia los aperturistas del sistema; pero tengo recortes de prensa de aquellos días en que el «bunker» y sus ideólogos se revolvieron furiosos e indignados contra la publicación de esas pacíficas páginas, exigiendo que se tomasen medidas contra su autor. Y eso no eran, no fueron, bromas. Sin embargo, muchos -es lógico- lo citan hoy en sus posteriores ediciones de 1983 o de 1992 yo creo que sin saber en absoluto de cuando es su primera, inalterada, edición, obviando además lo que de verdad pasaba en este país en aquellas circunstancias.

Yo no oculto que con ese libro, a la vez de informar -objetivo preferente- acerca de lo que se estaba haciendo desde tiempo atrás en filosofía y ciencias sociales en el campo democrático (Tierno, Aranguren, etc.), se trataba también de «animar» y de «rehabilitar»a los que procediendo del franquismo quisieron evolucionar (por ejemplo, Ridruejo, Ruiz-Gimenez, Laín y otros) para de hecho ayudar, con nosotros, a lo que enseguida sería la transición a la democracia. Tengo comprobado, con agrado, claro está, que por lo general quienes desde la oposición vivieron y sufrieron aquellas dificultades aprecian mi libro en mucho mayor medida, sin perjuicio de mil discrepancias y críticas concretas, que quienes lo leyeron después, o ahora, con todo aparentemente regalado. De todos modos, prefiero haber pecado por exceso, por comprensiva generosidad, que por defecto, por espíritu de revancha inquisitorial.

Otro tema, planteado en la pregunta, es si esas aportaciones hispánicas tienen mayor o menor valor objetivo. En esto soy realista y sé bien que lo mío tampoco está a más alto nivel que mucho de lo que yo reseño allí; puede que de algunas cosas sí, pero tampoco está prohibido hablar de lo que, en esa zona media, hacen los demás si lo intentan con respeto, trabajo y buena fe. No hay tanto, ni acá ni allá, que pueda situarse en ese nivel máximo de la gran excelencia y la suprema excelsitud. Y respecto de la «españolidad» -eso lo tengo claro-, por el momento sólo decir que ni casticismo patriotero ni cosmopolitismo de Gran Hotel, ni necio triunfalismo, ni masoquista autoflagelación. Todos los hombres y mujeres con espíritu universal que he conocido (o leído) están siempre primero y, a la vez, en su pueblo, con sus gentes, con su historia y su realidad: no para aislarse sino para tener cosas que comunicarse. Sólo desde lo singular y local -así lo creo- se accede a lo general y universal.

23. Por aquellas fechas una derivación de tu fijeza en temas relacionados con España fue tu insistencia en que trabáramos conocimiento 
con la filosofía jurídica que se hacía en América Latina. Te recordamos repitiendo que nuestra ignorancia era una vergüenza. De ahí salió directamente la tesis doctoral de Manuel Atienza. Pero el resultado fue un poco perverso: más y mejor filosofía analítica. Se entablaron, efectivamente, unas entrañables relaciones intelectuales con algunos países latinoamericanos, pero sobre unas bases que, aunque en lo personal sean muy gratificantes, en lo intelectual seguramente no te satisfacen tanto. Seguramente es dificil, pero nos gustaría que dijeras si eso es así y por qué.

Aplicación práctica y dinámica de la anterior teoría de la universalidad: unido en este caso a que la lengua, común, es (Unamuno) el «tuétano del alma» y un montón de cosas más. Cuando yo le insté -en 1974, creo que fue- al entonces muy joven Manuel Atienza a hacer su tesis doctoral sobre la filosofía jurídica en América Latina era porque, mientras conocíamos las ultimísimas publicaciones, libros y artículos de revistas, de autores alemanes, ingleses (también norteamericanos), franceses o italianos («más lejos», los portugueses), allí nos habíamos quedado en Carlos Cossio (Argentina), Eduardo García Maynez (México), Miguel Reale (Brasil) y me parece que muy poco más: Genaro Carrió, y sobre todo por su relación con Hart. Yo intuía -bueno, algo, algunos nuevos nombres como el de Ernesto Garzón ya había empezado a oír- que allí tenía que haber gente de interés. Y así fue. Acerté. ¡Y que lindo, viejos, lo que salió de aquella tesis del pibe Atienza!

A la cabeza de todos -puente de unión también entre España y Alemania-, nuestro hermano mayor, el mencionado Ernesto Garzón Valdés que incluso, sin saberlo yo y para más «inri», se había doctorado aquí, en Madrid, y a quien tanto tenemos que agradecer. Un recuerdo asimismo muy especial para Carlos Nino, reciente y muy prematuramente desaparecido cuando tanto quedaba que discutir con él: lo conocí en Oxford a la sombra de Hart y Dworkin. Y, después, sin incluir a filósofos de otras áreas, Carlos Alchourron, Eugenio Bulygin, Diego Martín Farrell, Juan Carlos Gardella, Ricardo Guibourg, Enrique Marí, Eduardo Rabossi, Roberto Vernengo... por referirme únicamente -hay más- a algunos de los que más he tratado y/o leído, siempre con provecho para mí. Aunque ahora, con manifiesta perversidad, los fautores de esta entrevista -analíticos confesos y, si siguen así, un día incluso probablemente mártires- me quieran enzarzar con buena parte de ellos -jno lo conseguirán!-, vaya para todos de verdad mi aprecio, crítico reconocimiento y amistad. Por lo demás, nadie es perfecto. ¡Ni siquiera los iusfilósofos argentinos!

Pero hablando de Latinoamérica no tendríamos que olvidar tampoco a los colegas de países, entre otros, como México (Óscar 
Correas, Rolando Tamayo, Rodolfo Vázquez), Venezuela (Lino Rodríguez Arias, Roque Carrión), Chile (Agustín Squella, Eduardo Novoa Monreal), Brasil (José Eduardo Faria, José Gerardo de Souza, Celso Lafer, Antonio Carlos Wolkmer, Celso Fernandes Campilongo); y en la Europa más cercana, Portugal, el valioso y activo amigo Boaventura de Sousa Santos. Todo ello y lo que falta configura, como se ve, un panorama bastante rico, no monolítico sino diverso y plural. Haría falta, acá o allá, un nuevo Atienza -ya sé que no es fácil- que con talante crítico y autocrítico se pusiera a remover y a estudiar todo eso otra vez. Pero ya no lo encuentro, ni siquiera apenas para nuestro propio país: en las jóvenes generaciones -ni así les hago reaccionar- están todos (bueno, casi todos) vendidos al dólar yanqui, al oro de Washington; sólo atienden a los créditos -pocos, la verdad- que les conceden desde allí. De todos modos, como ya señalé antes, entre los novísimos doctorandos parece que comienza a advertirse algún mayor interés hacia esa historia de la filosofía jurídica, ética y política de la España contemporánea. Es, creo, muy positivo que así ocurra, hasta -como vengo repitiendo aquí- para una mayor y mejor universalidad de nuestra vida intelectual.

24. Los años 76, 77 y 78 no pueden dejarse pasar así como así. La transición y la Constitución son acontecimientos históricos que se reflejan por fuerza en la tarea intelectual. Y más en un caso como el tuyo, claramente comprometido con el proceso. No nos interesa tanto el aspecto histórico como el aspecto institucional. ¿Cuál sería hoy tu opinión global sobre ese proceso?

Esos (1976-1978) son años muy importantes y entrañables: era, ante todo, el final de la dictadura. Parecía imposible, pero Franco, al fin, había muerto aquella inolvidable madrugada del 20 de noviembre de 1975: se abría así el tiempo para intentar realizar esas esperanzas, esas utopías políticas y sociales de libertad y democracia que afectaban también muy profundamente a nuestras vidas individuales. Es muy difícil que las generaciones actuales puedan comprender del todo lo que significaba para nosotros esa liberación de casi cuarenta años de dictadura -itoda nuestra existencia!-, días, miles de días, que para muchos en los primeros tiempos lo fueron de muertos a recordar y de infame persecución, y que para todos en la vida cotidiana lo eran -se reconociera o no- de continua humillación, de privación de libertad, de mentiras e injurias sin opción alguna para poder responder, de negación de la dignidad humana. Contra todo ello se luchaba como se podía, se construían además espacios privados donde hacer posible el trabajo y algún grado de libertad, y eso era lo que personalmente permitía seguir en pie, compartiendo tantos 
años con tantas gentes aquellas utópicas esperanzas simbolizadas en la recuperación de la democracia.

Estuvo bien, a pesar de todo, la ruptura pactada, las reformas que llevaron a la ruptura de la dictadura y a la transición a la democracia y a la Constitución. No se podía, ni tal vez se debía, haber hecho, en lo sustancial, otra cosa muy diferente. Reenvío, por si parezco aquí, en estos juicios, un poco terminante o dogmático, al capítulo «Las ideologías de (sobre) la transición» de mi ya citado libro Ética contra política. Reconozcamos, como han hecho la casi totalidad de los analistas extranjeros, que las cosas salieron bastante bien, lo cual no quiere decir, claro está, que se resolvieran por arte de magia todos los problemas tradicionales de centralismo, desigualdad, enfrentamientos y violencia, que -junto a otros nuevos problemas- se empezaron no obstante a plantear por entonces con mucha mayor participación, eficacia y seriedad.

He insistido en otros escritos míos en que, desde un punto de vista histórico, la transición fue fundamentalmente impulsada y demandada desde siempre por aquellos sectores, individuos y fuerzas sociales que componían, en sentido amplio, la oposición democrática a la dictadura. Pero fue, tuvo que ser, y repito que estuvo bien, una transición vía transacción, con entendimiento (en los dos sentidos de la palabra), negociación, consenso, pacto con los sectores aperturistas del régimen anterior que representaban intereses, también económicos, que precisaban adaptarse e integrarse en la nueva situación. A partir de ahí, decir -como están diciendo algunos contumaces y simplistas intérpretes- que la transición la hicieron los no demócratas es, en mi opinión, no querer, o no poder, entender lo que de verdad, y no sólo en la aparente superficie, acaeció.

Y desde un punto de vista institucional, por diferenciar, como se hace en la encuesta, esa doble entrelazada perspectiva, lo decisivo, claro está, fue el paso -ruptura- desde un Estado dictatorial (que lo fue siempre, aún con diferencias, tanto en su fase totalitaria como en la denominada autoritaria, con negación de derechos básicos y libertades políticas) a un Estado de Derecho que se configura más precisamente en la Constitución, y con serias potencialidades, como Estado social y democrático de Derecho. Aquel Estado dictatorial del franquismo -debiera ser obvio volver a señalarlo- significó siempre la real y formal negación de las instituciones, garantías y libertades imprescindibles y básicas de todo Estado de Derecho.

25. Desde antes de esos años tu militancia en el Partido Socialista Obrero Español es conocida. Entonces parecía natural que un intelectual asumiera un compromiso político. Vamos a hacerte 
dos preguntas al respecto. La primera: Desde la teoría política. ¿Cómo ves la función del partido político en la sociedad democrática? La segunda: ¿Es tan claro el vínculo entre actividad intelectual y militancia política como parecía entonces?

Fue en el grupo socialista de Tierno Galván, impulsado muy activamente por Raúl Morodo, donde -finales de los cincuenta, comienzos de los sesenta- yo comencé con algún tipo de actividad política en la oposición ilegal al régimen del general. Allí estuve casi diez años haciendo lo que cabía hacer. Después me distancié, cuando en 1968, aquél fundó un PSI conflictivo con el PSOE (de ello he hablado en mi libro Socialismo en España), y en 1974 en Asturias, donde había ido como catedrático de la Universidad, se inició ya mi acercamiento y colaboración más o menos formal con el clandestino Partido Socialista Obrero Español. Aunque yo tenía firmemente decidido no dedicarme de manera, digamos, profesional u oficial a la política, es decir no optar ni aceptar cargos políticos, pensé, no obstante, algo después que inscribiéndome como militante de base podía ayudar más a la causa común y a la necesaria extensión y aceptación (legitimación) de los partidos y, en concreto, del partido socialista: el empujón final me lo dio Peces-Barba emplazándome a ello en conversación, los dos, con Felipe González. Estábamos, recuérdese, en una España que salía en aquellos momentos de un régimen como el franquista que desde siempre había puesto todo su máximo empeño, su mayor insistencia y prepotencia propagandística y hasta policial, en el objetivo precisamente de desprestigiar y perseguir a toda costa y por todos los medios a los partidos políticos, el mal absoluto -no se olvide hoy- para todos los jerarcas, corifeos, seguidores y escribidores de aquel monolítico Estado dictatorial.

¡Como han cambiado los tiempos! Entonces la decisión de trabajar (nunca me gustó el verbo «militar») en un partido, sobre todo de izquierdas, se veía -¡con perdón!- como un acto de generosidad, de dignidad, de ética democrática, incluso de estar dispuesto a asumir un cierto mayor riesgo ante lo que todavía pudiera pasar; el 23-F del 81 hubo ya «milicos» que empezaron a solicitar y a buscar las listas y archivos de los partidos: muchos de los que hoy más blasonan de «independientes» sólo fueron entonces, quedándose fuera, muy cautos y prudentes; también es verdad que en medio entró, junto a mucha gente sana, más de un aventajado oportunista. De todos modos, querría dejar bien claro que, lo mismo que no identifico en absoluto al llamado «independiente» con la objetividad y la imparcialidad (hay muy diferentes tipos de «dependencias» $y$ todos somos de un modo $u$ otro «interdependientes»), por otro lado, tampoco pienso que el compromiso ético y político con la sociedad -del intelectual 
o del manual- tenga necesariamente que concretarse y formalizarse en militancia política -para nada fanática ni sectaria- en uno u otro partido. Se puede trabajar, y bien, por la democracia de muy diferentes maneras y en muy diversos ámbitos.

Pero los partidos políticos me parecen, eso sí, necesarias organizaciones con coherencia interna y externa que pueden y deben contribuir a vertebrar la colectividad, junto a los movimientos sociales y otras formas de asociación, ayudando a formar, canalizar y expresar la opinión pública, piezas institucionales absolutamente imprescindibles en un sistema político democrático. Obvio también -y en esto se insiste justamente hoy- que la democracia no debe de ningún modo reducirse a excluyente partitocracia (García Pelayo) y que, a su vez, los propios partidos deben constituirse y funcionar de manera plena y abiertamente democrática.

26. Una pregunta comprometida: Desde tu perspectiva teórica ¿qué añadirías y qué suprimirías de la Constitución Española de 1978?

Renuncio aquí, por razones obvias de tiempo y espacio, a la práctica pormenorizada, ni siquiera seleccionada, del juego del «quita y pon» en relación con nuestra Constitución. Hay sin duda en ella términos concretos que se podrían cambiar, artículos que habría que redactar mejor, conceptos que se necesitarían aclarar para su mayor coherencia y sistematicidad, muchas cosas a conectar de modo más directo con una realidad social que se quiera progresivamente transformar. En los numerosos comentarios publicados existe ya base suficiente, incluso artículo por artículo, parágrafo por parágrafo, para semejantes propuestas de técnica -y política- revisión, la cual daría lugar a debates, con toda seguridad, difíciles en muchos casos de solventar.

Pero me parece que nuestros problemas no derivan hoy en forma alguna de esas hipotéticas deficiencias e insuficiencias del texto constitucional. De todos modos, y sin ser yo especialista en el tema, desde el principio he echado de menos que en el complicado, delicado e inestable Título VIII no se hubiera podido configurar, identificar y nombrar sin más al Estado de las autonomías como claro y explícito Estado federal. Por ello estoy también ahora de acuerdo con quienes propugnan la reforma legal (art. 69) que haga del Senado una verdadera y operativa Cámara de representación territorial. Sería, me parece, lo único que en las actuales circunstancias convendría tocar y modificar (tras las dos palabras añadidas, por imperativo europeo, al art. 13 en 1992).

En la Constitución tenemos así un válido, fuerte y legítimo fundamento 
para la convivencia pacífica y democrática de los españoles, convivencia institucional y también plurinacional en el Estado común; y todo esto es, por supuesto, lo esencial. Pero, junto a ello y sobre ello, existe también -quisiera remarcarlo en estas páginas de manera muy especial- base y potencialidad para su aplicación y realización en coincidencia con las políticas de progreso que pueden y deben impulsarse (¡incluso en nuestros días!) desde las posiciones propias del socialismo democrático. Reenvío para la ampliación acerca de esas potencialidades a mi trabajo «El Estado democrático de Derecho en la Constitución española de 1978», incluido en mi ya citado libro Socialismo en España: el partido y el Estado.

Solamente recordaré aquí para olvidadizos y frente a quienes, vía conservadora, se empecinan en su unilateral y restrictiva interpretación, un muy breve sumario de algunos de los preceptos que, en coherencia con la totalidad, pueden servir de puntos más concretos de apoyo para esa progresiva lectura y realización: así, desde el Preámbulo, donde se proclama ya la voluntad de «establecer una sociedad democrática avanzada», o el art. 1 por el que «España se constituye en un Estado social y democrático de Derecho», hasta todo el capítulo segundo con el establecimiento, no retórico, de los «derechos y libertades de los ciudadanos», pasando por el art. 9 que encomienda «a los poderes públicos promover las condiciones para que la libertad y la igualdad del individuo y de los grupos en que se integra sean reales y efectivas». O -por resumir al máximo- todo el título VII sobre Economía y Hacienda donde se dice (art. 128) que «toda la riqueza del país en sus distintas formas y sea cual fuere su titularidad está subordinada al interés general»; o (art. 129) donde se señala que los poderes públicos «establecerán los medios que faciliten el acceso de los trabajadores a la propiedad de los medios de producción»; o el ya citado art. 131, en el que se dispone que «el Estado, mediante ley, podrá planificar la actividad económica general para atender a las necesidades colectivas, equilibrar y armonizar el desarrollo regional y sectorial y estimular el crecimiento de la renta y de la riqueza y su más justa distribución».

27. Desde aquel momento siempre te has mostrado como un infatigable «componedor» de las posibles fracturas y dispersiones del socialismo español. Participaste en la incorporación del PSP, clamaste contra la división latente en el famoso XXVIII Congreso, nunca te has identificado ni has querido jugar a eso de las etiquetas. No queremos una definición personal, sino una reflexión teórica para responder a esta pregunta ¿Cuál es la razón por la que tiendes a optar siempre por la unidad? ¿Por qué no la fragmentación si obedece a posiciones de fondo? 
Aunque entre hispanos casi parezca peyorativo, «componedor», quien compone, así pues también «compositor», es la persona que tiende a formar un todo juntando o disponiendo cosas o partes diversas (como se ve, he tenido siempre muy a mano el Diccionario de la Lengua Española: no en vano conozco bien a mis metódicos interrogadores). Sí, estoy de acuerdo como rasgo más general en que a la postre yo prefiero componer a, sólo, descomponer; prefiero lo que es y está compuesto -las cosas no son nada simples- a aquello o aquel que siempre está o anda descompuesto, incluso mentalmente. Enlazando con lo que ha vuelto a recordar Norberto Bobbio en un reciente libro, yo subrayaría que la función intelectual es, en muy amplia medida, una función crítica, desde luego, ejercida desde convicciones pero por ello mismo también, responsablemente, una función de «mediación» entre gentes o posiciones (no todas, no cualesquiera) que se empeñan, a veces irracionalmente, en no entenderse -ni a sí mismos ni a los demás-, en no buscar más lo que une que lo que separa con consecuencias a veces muy negativas para todos.

Ya sé que aquí sólo se me pregunta estricta y exclusivamente y con toda claridad por esa actitud mía en relación con el socialismo español de esos años: aprovecharía, sin embargo, para advertir con carácter más general y también sobre esa tarea de «mediación» intelectual, que no habría que malinterpretar y desorbitar ese talante de entendimiento y composición desde esa propia tendencia «a optar siempre por la unidad». Jamás, por ejemplo, se me ocurrió nunca unificarme con los que en el anterior régimen querían unificarnos a todos a la fuerza. Y así en otras muchas ocasiones. Junto a la unidad -incluso en el socialismo español- he defendido siempre asimismo la pluralidad, el pluralismo, la diferencia y el derecho a ser diferente.

Lo que también en este ámbito he observado con frecuencia, y lo que se puede por desgracia seguir observando en demasiadas ocasiones, es que la fragmentación, la desunión e, incluso, el enfrentamiento mordaz entre unos y otros no obedece siempre a posiciones de fondo, a actitudes serias no compaginables objetivamente sino más bien a personalismos o amiguismos en competición por parcelas de poder; es decir, a apriorismos o -por el contrario- a hechos consumados que, por lógicos y respetables que a veces sean, no tienen tampoco derecho ni justificación para arrastrar a los demás y producir rupturas que, como digo, pueden acabar siendo muy negativas para intereses, valores y metas desde luego de muchísima mayor trascendencia pública y general. Diferencias, pues, y pluralidad (eso es la democracia) pero no, sin más, sacralización de la fragmentación. En concreto en los dos casos que ahí se citan creo que tenía plena razón aquella invocación a la unidad: ni PSI-PSP era, ni tenía porque ser, tan diferente al PSOE, ni -dentro de este- en 1979 hubiese sido mejor la ruptura (ni los críticos 
ni los oficialistas la deseaban) que, con discrepancias, la prosecución de la historia y el trabajo común. Tampoco hoy me parece que debamos resignarnos a aceptar la reducción del pluralismo a ese tan rígido modelo binario -obsesivamente potenciado por algunos medios de comunicación- entre «guerristas» y «renovadores», apenas aliviado por la buena utopía de «izquierda socialista», como etiquetas únicas y fijas en el seno del actual socialismo español. Yo soy más bien pluralista e integrador: creo posible el entendimiento a pesar de las discrepancias reales y de las distancias personales.

28. Tu nunca has sido comunista, pero hay que reconocer que incluso para los que no lo han sido, el derrumbamiento de la URSS y sus «satélites» ha sido algo insólito. ¿Ha afectado a tu pensamiento? ¿Qué consideras vivo y qué consideras muerto en el marxismo?

El derrumbamiento de los sistemas comunistas ha sorprendido, en efecto, a propios y extraños: incluso, en Estados Unidos y otros países, a prestigiosos Institutos de Sovietología y a tantos y tantos de sus sesudos y documentados especialistas. No es que ya, en los años ochenta (o antes), se creyera mucho en sus virtudes o en su eficacia pero me parece que nadie esperaba un hundimiento tan rápido, tan absoluto y espectacular y unos escombros tan pobres, tan vergonzantes, impúdicos y desorbitados en sentido contrario. Esperemos, de todos modos, que todo este caos se pueda reorientar debidamente en los próximos años: algo ya se empieza a advertir tras el capitalismo mafioso y salvaje de los primeros momentos.

En este sentido es verdad que, en los viejos tiempos, alguna esperanza voluntarista tuvimos los no comunistas (pero también otros, los mejores de ellos, desde dentro) en que se pudiera un día acabar saliendo de aquellos regímenes totalitarios hacia convergencias democráticas y socialistas con los sistemas pluralistas y parlamentarios occidentales. Y ello a pesar de la mala herencia del Lenin de la disolución de la Asamblea Constituyente en enero de 1918 y a pesar, sobre todo, de la larga y sanguinaria dictadura del padrecito Stalin que -muerto en 1953- veíamos ya, en cualquier caso, como un negro y lejano pasado que aquellos regímenes tendrían que superar. Sin duda que las represiones en Hungría en 1956, Berlín en 1961 (yo estuve allí) o Praga en 1968 no eran precisamente impulsos en esa democrática dirección, como no lo era tampoco la situación general en la URSS. De todos modos, todavía Gorbachov, aclamado en el amplio mundo, se nos aparecía como aquella última buena (im)posibilidad. Pero ha hecho falta, ya se ve, el completo hundimiento de ese totalitarismo para que puedan volver a tener allí espacio algunas de aquellas viejas esperanzas de mayor igualdad y libertad. 
Incluso a los que nunca fuimos comunistas pero colaboramos con ellos, o ellos con nosotros, sin confusión, bajo y contra la dictadura franquista, por supuesto que nos ha afectado, teórica y prácticamente, ese proceso de final aniquilación y degradación. En todos ha influido esta historia. Pero es la más reaccionaria e increíble derecha la que, en estos primeros momentos, ha sacado el máximo provecho de tal situación. Y aunque se diferencie con claridad, también todo ello repercute sobre filosofías y pensamientos, como es el de Marx, de los que con tanta frecuencia se usó y, a mi juicio, ilegítimamente se abusó en aquellos regímenes.

Para ese elenco que se me pide sobre «lo vivo y lo muerto» en el marxismo, reenvío - ique lo lea quien lo quiera saber!- al capítulo tercero sobre «Marx y la teoría marxiana del Derecho y del Estado» de mi libro De la maldad estatal y la soberanía popular. Sólo añadiré aquí que estoy por la lectura no (unilateral y reductivamente) mecanicista, determinista y totalitaria de la obra de aquel y a favor de su (posible) interpretación como filosofía humanista (humanismo real), dialéctica (pluralidad de factores en la producción de la realidad) y democrática (con libertad y sufragio universal). Recordemos, por ejemplo, aquel texto de Marx, de 1852: «Pero el sufragio universal equivale al poder político para la clase obrera de Inglaterra, donde el proletariado constituye la gran mayoría de la población [...] Imponer el sufragio universal en Inglaterra -concluía aquél- sería, pues, una medida mucho más socialista que todas las que se han honrado con este nombre en el continente». Y así, casi al final, en 1880 (Marx murió en 1883), insistirá en la necesidad de transformar el sufragio universal «de medio de engaño que ha sido hasta aquí en instrumento de emancipación». Desde luego -jlo siento!-, hay que seguir leyendo a Marx.

29. No parece ser ir muy contracorriente que en plenos años ochenta te plantees una defensa del Estado contra sus críticos izquierdistas. Se diría más bien que a partir de esos años se necesitaba una defensa contra sus críticos derechistas. No te vamos a preguntar cuál es el papel del Estado porque eso sería encargarte otro libro, pero quizás puedas arriesgar una respuesta sobre la diferencia entre unos y otros atacantes.

En cuanto a quien sea el principal destinatario de mis posiciones críticas, podría -creo- diferenciar en mis escritos y argumentaciones dos (y hasta tres) muy diferentes, sucesivas, etapas: bajo la dictadura el adversario era la derecha, especialmente la que apoyaba dicho régimen, tanto en sus concepciones ideológicas (por ejemplo el iusnaturalismo) como, más tarde y a la vez, en sus reducciones cientificistas 
(por ejemplo el tecnocratismo); pero después de 1975-76, en retroceso esa derecha totalitaria, es verdad que en las primeras fases de la transición a la democracia, mi diálogo crítico -muy distinto, claro está del anterior- se entabla más bien en el seno de la izquierda con algunos sectores radicales y extremosos de ella: este es, a pesar de todo, así lo veo yo, un diálogo interno, mientras que aquél -frente a la dictadura- lo era totalmente externo.

En esa perspectiva interna habría, pues, que situar el trabajo, de 1977, sobre precisamente «El Estado democrático de Derecho y sus críticos izquierdistas» incluido en mi libro Legalidad-legitimidad en el socialismo democrático y, después (a ello, creo, es a lo que se alude en la pregunta), la obra de 1984, ya mencionada en la nota anterior, De la maldad estatal y la soberanía popular. Pero no creo en modo alguno que ese diálogo crítico con la izquierda radical carezca, por la otra banda, de consecuencias e implicaciones de rechazo para el destinatario, principal postrer adversario, que es esa derecha liberal conservadora tan prevalente y prepotente en estos últimos tiempos. No hay nada mejor que una mala izquierda para que triunfe la peor derecha. En el fondo, y esto se advierte ya con mayor claridad en mi libro Ética contra política, de 1990 -ésta sería la mencionada tercera etapa crítica-, el oponente era dual o, incluso mejor, lo era esa desigual amalgama, esa confusa y ambigua pero nada irreal conjunción, que allí se calificaba como «liberal-libertaria».

Es en ella donde se produce esa ideología de la maldad estatal, la casi total demonización y culpabilización de las instituciones políticas, la casi absoluta deificación (y reificación) de la sociedad civil. El resultado, con total ventaja del más astuto y poderoso liberalismo conservador sobre el más ingenuo y débil libertarismo radical, era la reducción cuantitativa y cualitativa del Estado social, la imposición de la ideología del «Estado mínimo» y la ampliación aún mayor de poderes para las grandes corporaciones y las redes de agencias transnacionales de la sociedad civil (más bien, mercantil). Se trataba y se trata, por tanto, de liberar a los buenos libertarios (gentes de izquierda) del maléfico influjo y poderío de esos liberales (gentes de derecha). Y, en cambio, de dar paso al nuevo "pacto social», Estado democrático de Derecho, a construir progresivamente a través de la no imposible colaboración entre las instituciones políticas de la socialdemocracia y los movimientos sociales (ecologistas, pacifistas, feministas) herederos del mejor libertarismo.

30. Un postulado teórico que va adquiriendo más y más importancia en tu pensamiento es el de la justificación o legitimidad del sistema político en torno al principio de mayorías. Hasta el punto de que hay quien puede suponer que le das un alcance que llega a invadir 
otros criterios de legitimidad, como el de los derechos humanos. Dinos si hay en tu pensamiento una marcada tendencia al «monismo» valorativo o si en este tema admitirías un pluralismo de criterios, con todos los problemas que ello implica?

Este tan grave problema se conecta incluso con el de la tensión entre las denominadas Gesinnungsethik, ética de convicciones, de principios, de intenciones, ética deontológica (Kant) y Verantwortungsethik, ética de la responsabilidad, de las consecuencias, utilidades, ética teleológica (Mill), si se me permiten además todas estas aproximativas equivalencias internas. Yo estaría, creo que con Weber, por un -desde luego, todo menos que fácil- intento de compatibilizar y tratar de dar solución a los conflictos entre ambas dimensiones: una ética de principios consecuentemente responsable; responsabilidad también en términos reales, económicos, sociales, políticos, culturales, incluso de identidad personal y moral. No, pues, una ética apolítica, fundamentalismo «justiciero» aunque perezca el mundo, ni una política amoral, inapelable oportunismo facticista y eficientista. ¿Es eso «monismo» o «pluralismo» valorativo?

Sobre esas bases (sólo orientativas con carácter muy general pero pienso que nada inútiles) vayamos al punto en cuestión sobre el que se produce, es lógico, bastante perplejidad y, en ocasiones, no poca ambigüedad. Por un lado se suele y se quiere afirmar y definir -y me parece bien- que la legitimidad de un sistema político democrático depende de la participación libre y universal en la toma de decisiones; y no de que alguien o algunos consideren que, a pesar de ello (a pesar de la que denominaban peyorativamente en otros tiempos como mera «democracia formal»), no se da suficiente participación en resultados medidos en mayores cotas de igualdad, necesidades, bienestar, justicia, o sea, «democracia material o real»: desde ahí se descalificaba la primera, e incluso toda la democracia sin más, si esta segunda no era lo que desde esos sectores (radicales de izquierda) se propugnaba -y, con frecuencia, no injustamente- que debía ser. Pero, por otro lado -y ello puede aparecer como contradictorio con la anterior reivindicación y definición de la legitimidad democrática como libre proceso de decisión-, se pone también en guardia por otros sectores (más de derecha, liberales y conservadores), y esto es lo prevalente hoy en la mal denominada teoría de los derechos (morales), que esas decisiones democráticas expresión de la libertad positiva carecen de legitimidad para intervenir e interferir en ciertas zonas de la acción o condición humana (libertad negativa). En ambas perspectivas lo que está en juego es la correcta relación entre el origen y el contenido de la democracia, es decir la doble participación -en decisiones y en resultados- que define a ésta. 
El problema radicaría, claro está, en determinar que es lo que en concreto no se puede, justa y legítimamente, hacer: los obispos dicen, invocando a Dios, que el Estado democrático, o sea con la mayoría de la sociedad y de la gente detrás, no puede bajo ninguna circunstancia o condición legalizar, ni legitimar, el aborto, la eutanasia o el simple uso de anticonceptivos como control «artificial» de la natalidad; muchos de los grandes propietarios, banqueros y especuladores, por su parte, también consideran realmente sus fincas, mercados y capitales como de Derecho natural -tengo textos preciosos de uno de ellos, hombre culto, alto cargo del Opus y de la Banca-, bienes que, por tanto, en lo «esencial» el Derecho positivo no puede tocar; y así sucesivamente. ¿Cuál es el (auto)límite? Porque haberlo lo hay: adelanto que para mí lo es la básica libertad.

Resulta, por lo demás, curioso e interesante de constatar y de resaltar -bajando ahora a circunstancias históricas concretas- cómo el gran miedo y la delicada prevención de ciertos teólogos, moralistas y iusfilósofos así como de otros escribas y periodistas, frente a decisiones políticas y legislativas que pudieran afectar a valores éticos y derechos humanos -objetivo sin duda imprescindible y fundamental- se produce y cobra gran auge en nuestro país precisamente y de modo muy preferente sólo después de 1975-1976 con la llegada de la democracia y, todavía aun más, después del 82 ¡con mayoría absoluta de los socialistas! Pero para nada se autoexigían la mayor parte de aquellos tales denuncias cuando en aquella pobre y sufrida España quienes decidían, es decir quienes hacían y deshacían, de manera absolutamente despótica y dictatorial, eran muy reducidas y poderosas minorías totalmente concordes con los dogmas del integrismo católico tradicional. Entonces eran sólo los demócratas quienes luchaban, teórica y prácticamente, por la libertad, por los derechos humanos, la vida, la ética, la igualdad y la dignidad personal.

$\mathrm{Y}$, precisamente, estos son los grandes valores que configuran con coherencia interna el ámbito ético en que se produce, se fundamenta y se enjuicia críticamente la legitimidad, y la legalidad, democráticas: así, la participación en las decisiones implica allí, como base imprescindible para la formación del criterio de las mayorías, el respeto a la libre voluntad de todos, individuos y minorías, el debate común más racional e ilustrado posible y, también, la formación de posibles consensos, pactos y acuerdos; por su lado, la participación en los resultados -recuérdese, la doble participación- exige para todos cobertura, protección y realización de las necesidades básicas (sanidad, educación, seguridad social...) y de los derechos fundamentales, igualdad real de oportunidades, reconocimiento del derecho a la diferencia y, asimismo, del esfuerzo, la capacidad y el mérito, todo ello con políticas de redistribución para una mayor igualdad... 
Con estos criterios no se tiene ya en la mano, por supuesto, la receta mágica, la fórmula exacta e infalible para resolver absolutamente todos los supuestos de la casuística moral y, ni siquiera, de la vida real; la tal fórmula yo, desde luego, no la sé ni -como suele decirse- sé de nadie que la sepa. Las discrepancias concretas, con diverso reconocimiento de tales criterios, van sin duda a continuar; pero constituyen, así lo creo, materiales muy válidos, imprescindibles, para mejor orientarlos y tratar de darles la más justa y adecuada solución, en un sistema político democrático y en una sociedad adulta, libre, ilustrada, éticamente responsable.

31. Tiene relación con lo anterior. Has asumido muy decididamente el valor democrático de los llamados «nuevos movimientos sociales». ¿No crees que son movimientos que tienden a interceptar el proceso electoral, a modificar desde fuera de las elecciones los programas de gobierno?

No, nada, en modo alguno. En este punto, por decirlo suavemente, veo a los encuestadores bastante fuera de la realidad, o de lo que -también para ellos- debiera ser la realidad. ¡Hombre, todo, absolutamente todo, tiene sus riesgos y sus exageraciones y no iban a ser menos los nuevos movimientos sociales! Pero ¡ojalá que las principales necesidades ecológicas y aspiraciones ecologistas, o las exigencias de las asociaciones de usuarios y consumidores, pongo por caso, tendieran a modificar aún más los programas de gobierno! Habría -sin milagros- muchos menos incendios de bosques, una lucha mucho más eficaz y decidida contra la desertización de nuestro territorio, menor contaminación en las ciudades, mejor política hidrológica tanto en las regiones húmedas como en las secas, mayor control en la sanidad o en la alimentación, etc., etc. Y todo ello, esa recepción crítica y selectiva, para nada tiene por qué «interceptar el proceso electoral».

De esto es de lo que se trata: también de que la gente que, por lo que sea, no quiere trabajar en las instituciones, en los partidos, ayuntamientos, sindicatos, etc., lo haga en esos movimientos progresistas de la sociedad civil o en otras importantes organizaciones no gubernamentales que hacen más denso y tupido el tejido social. Como ya se indicó aquí, en el final del punto veintinueve, lo importante es el pacto, proceso siempre abierto, la colaboración no exenta -desde luego- de problemas y conflictos entre instituciones políticas y movimientos sociales: que aquellas no se enquisten y se aíslen de la sociedad, tampoco de estos sectores nuevos de ella, que estos no se sitúen necesaria y aprioristamente en ruptura y siempre en actitud de no negociación con la Administración, Parlamentos, partidos 
demás. Reléase, por favor, sobre ello -y en relación con las actitudes de Claus Offe- el epígrafe VI, 3, de mi libro Ética contra política, titulado precisamente «El nuevo pacto social: instituciones políticas y movimientos sociales»; allí hay también buena bibliografía para proseguir y progresar en este central tema de nuestro tiempo.

La democracia es participación, doble participación, en las decisiones y en los resultados, o sea, preferentemente participación institucional y social, aunque con fundamentales entrecruces e interferencias mutuas. El criterio básico e insuprimible para la legitimidad democrática -queden tranquilos de nuevo mis interlocutores, no tenían porque no estarlo- es, ya se ha dicho, la participación libre y universal en ese proceso de decisión; pero -véase el punto anterior tampoco podemos negar, ni ellos ni yo, que, por un lado, la ética digamos racional y, por otro, la fáctica, sociológica, legitimación (y deslegitimación), sobre la que pesa de manera poderosa la segunda participación (resultados, necesidades, bienes, otros derechos y libertades), tienen también fuerte influencia sobre aquella, primera y primordial, legitimidad.

\section{2. ¿A qué no te atreves a hablarnos del famoso «mercado»?}

¿Cómo no? Lo que ustedes manden. A estas alturas de tan fornido y exigente cuestionario, uno -pero no querría aparecer tampoco como un irresponsable- ya se atreve con todo. Además, con tanto como ya llevo escrito hasta aquí, no voy a dejar ahora en blanco precisamente este crucial punto treinta y dos. Estoy acabando -iqué remedio!- tomándome esta entrevista como un examen - ¡con libros!- y, aunque no soy economista, algo tendré que contestar también sobre ello. Me disculpo de antemano, pues.

Se me pregunta por el «famoso mercado» ¿Por cuál? Maite y yo, siempre que viajamos juntos, solemos invariablemente visitar el mercado de la villa o ciudad: sobre todo cuando llevamos nuestro propio coche para poder «cargar» con productos autóctonos y de buena calidad sacados de la huerta, la montaña o el mar. Y lo mismo hacemos en el extranjero, Inglaterra y Alemania en especial. Nosotros siempre visitamos antes las calles y los mercados que las librerías y los museos (después). Y es que es verdad, y así hay que señalarlo, que el mercado sirve muy bien para conocer más de cerca la vida de la ciudad y del país donde uno está, qué producen y qué consumen sus gentes, hasta los distintos modos de vender y de comprar. Claro que en nuestro tiempo la monolítica uniformidad -lo mismo nacional que trasnacional- va suplantando cada vez más la diversidad de esa originaria competitividad; comprendo, de todos modos -no hay que ser retrógrado-, que la organización a escala 
más amplia del comercio y del intercambio es inevitable y tiene también sus grandes ventajas pero debería siempre preservarse ese espacio rural, regional y local. El problema, uno de los problemas, es quien controla al final esa creciente organización: si los propios participantes a través de una u otra forma de provechosa cooperación o algún más poderoso monopolio (u oligopolio) exterior que indefectiblemente acaba siempre imponiendo su ley.

Vinculados a todo ese tinglado hay otros más fuertes mercados, que para mí -sin duda que por falta de posibles para entrar en ellos- resultan más opacos, impenetrables y antipáticos (me temo que, con esto, los grandes rentistas y agiotistas me van a tachar hasta de agrarista y preindustrial): son ellos los mercados de valores y capitales, mercados financieros, y los mercados de divisas, mercados monetarios, donde los pudientes pueden ganar (o perder) muchísimo dinero sin salir de casa y sin dar un solo palo al agua. En concreto en las especulaciones monetarias internacionales, cualquier canalla de alto nivel le puede despojar a todo un pueblo de miles de millones de sus reservas de dólares o marcos en un abrir y cerrar de mercado y ordenador. Para aminorar esto -que ya sé que pasa porque algo no va bien- se han inventado, desde luego algunas formas de regulación. Y también sé que la acumulación es productiva y que se fomenta la riqueza con los rendimientos del capital: el problema, otro de los problemas -junto al de la pobreza y la gran desigualdad social, salvo pues al pequeño y medio ahorrador, no al gran especulador- es quien controla en última instancia tal acumulación y quién y hacia dónde se orientan los excedentes y el volumen de inversión; es decir, en definitiva, al servicio de quien está una economía y como se hace más legítima y concorde con la justicia. En cualquier caso, mi opción es por una economía real, industrial y productiva, y no por una economía ficticia y meramente especulativa.

Desde luego que nadie en su sano juicio lo deja todo -especialmente todo lo que de verdad le interesa- en manos del mercado, de esa tiranía y/o de esa anarquía por tantos denunciada: no todo es, ni debe ser, mercancía, ni en lo privado e individual ni -menos- en lo público y social. Por lo demás, en el mercado si no llevas dinero, o llevas poco, no te venden nada, ni sanidad, ni educación, ni jubilación, o te la dan de bajísima calidad; ahora algunos quieren -es verdad que todo cuesta dinero- que el Estado se evada también de esa responsabilidad. Hasta el Estado intentarán privatizar; siempre lo ha estado (el Estado) y siempre lo estará, privatizado, acusará indomable algún rojo terminal. Para ampliar en torno a ello reenvío a lo aquí antes ya dicho, en los puntos doce y trece, sobre la necesidad de que un sector público social y un sector público estatal vengan a reequilibrar y planificar en beneficio de los intereses de todos y contando 
también con el mercado (economía mixta) la buena y justa organización de la sociedad democrática actual. No digo, repito una vez más, que sea fácil de lograr: sobre todo a escala transnacional.

Frente a los que están por la deificación del mercado (el elemental quiasmo, lleva así a la consiguiente mercantilización de los dioses) y por la absoluta y obsesiva imposición de una competitividad a veces muy poco o nada competente, habrá en todo momento que insistir -tal haría aquí yo- en que la llamada economía de mercado no agota ni satisface en modo alguno las exigencias principales de una sociedad democrática actual. Que, en definitiva, mercado y democracia no se identifican ni deben identificarse sin más entre sí; respecto de ello y aunque haya también su buena relación, de lo que debe hablarse -yo ya lo hice- es más bien de la «falacia de la identidad». Desde ahí y como, insisto, yo no soy economista, querría finalizar este ya largo apartado recordando palabras textuales de precisamente un economista y escritor a quien aprecio y respeto, John Kenneth Galbraith: «La corrupción -señala éste- es inherente al sistema capitalista porque la gente confunde la ética del mercado con la ética propiamente dicha». Y se pregunta buscando, como aquí, una conclusión: «¿Recetas para curar sus agravios? Una muy concreta: combinar la acción del mercado y la acción del Estado para corregir las grandes diferencias que hay entre los ricos y los pobres, para eliminar las deficiencias tremendas que hay en las ciudades, para luchar contra la pobreza, el crimen y el desorden. Para hacer que la sociedad sea más humana». ¿Vale así?

33. Pareces desde el principio más filósofo político que filósofo jurídico. ¿No comporta eso un cierto desapego a lo jurídico? Y al final «Ética contra política», es decir, más ético que político. ¿Cómo conjugas esas cosas?

Aunque no se deben confundir, tampoco se deben -creo- escindir esas mencionadas dimensiones -ética, política, jurídica- de los problemas sociales; tampoco otras, como la cultura, la economía, que se articulan en abierta totalidad. En ese contexto, y todo sumado, quizás a mí me ha interesado más la filosofía política que se propondría una doble función: una, digámoslo así, más sustancial y específica, de clarificación y debate sobre pros y contras de los diferentes regímenes y sistemas de organización pública de los poderes y la convivencia social; otra, de interrelación -pero desde esa perspectiva- con esos plurales factores y dimensiones, ética, jurídica, económica, cultural, de la entera realidad (totalidad) social.

Mis orientaciones y preferencias van, pues, hacia esa filosofía política que tiene mucho que ver con la filosofía ética (legitimidad-justicia) 
pero también con la filosofía jurídica (legitimidad-legalidad). No sé si todo esto se logra siempre «conjugar» bien -habría que añadir además la historia y la sociología- pero al menos ese es mi propósito y mi punto de vista. Desde luego que me interesa y me preocupa más esa filosofía política (ética y jurídica) que otro tipo de tratamientos, por supuesto que imprescindibles y del todo respetables: así, de tejas abajo, una estricta teoría jurídica y una dogmática jurídica, pero, como digo, tienen mi completo reconocimiento quienes la hacen, lo mismo que otras artes y ciencias; y, de tejas arriba, una teoría moral que se ocupa de otros temas más alejados de esa filosofía política y social; otra cosa es cuando ese alejamiento es falso (ideológico, ocultador) y carente incluso de justificación ética; pero, otra vez, claro que aprecio la lógica deóntica y la meta-ética aunque no sean mi especialidad. Hay sitio -creo- para todos, o casi todos, en la comunidad científica e intelectual, y cuando las cosas se hacen bien todo contribuye a entender y entendernos mejor.

No sé si tendría incluso que añadir que reconozco que esas preferencias y dedicaciones profesionales, docentes e investigadoras, derivan también muchas veces de limitaciones propias, personales y circunstanciales, que a la postre resultan difíciles de superar. Lo que quiero decir es que «en abstracto», y puesto a elegir, yo hubiera preferido ser, por ejemplo, un buen matemático o un destacado violoncelista, o también un físico o un biólogo que hubiera podido trabajar en los límites mismos del origen de la vida y de la materia... Me he tenido que conformar -en los dos sentidos de la expresión- con estos, no inútiles, trabajos de filosofía jurídica, política y social.

34. En otro orden de cosas no podía faltar aquí tu especial protagonismo en la revista «Sistema». Más de cien números autorizan a cualquiera a considerarte una especie de termómetro o sensor de la actividad intelectual de este país. ¿Cómo la has visto evolucionar desde ese observatorio?

El primer número de «Sistema» se publicó en enero de 1973, todavía bajo el régimen anterior: son ya, pues, más de veinte años de existencia y, cuando escribo estas líneas -verano del 94-, el último volumen aparecido es el capicúa 121. Ahí seguimos, aunque confieso que en medio de no pocas, muy diversas y hasta contradictorias, dificultades. A pesar de todo, «Sistema» ha sido y es una revista que, de manera fría y objetiva, creo que podría calificarse de importante. Está mal que yo lo diga, como director desde siempre de ella (con José Félix Tezanos como eficaz «editor» y Alfonso Guerra como presidente de la Fundación), pero es obvio que el mérito corresponde muy principal y esencialmente a los cientos de tan relevantes colaboradores 
que durante todos estos años han publicado allí sus artículos, notas y críticas.

En diferentes momentos de la vida de la revista hemos editado números monográficos y conmemorativos que, de un modo u otro, nos han dado pretexto y ocasión para un detallado ejercicio de revisión -creo que ni autocomplaciente ni autoflagelante- tanto en relación, punto de vista interno, con el propio significado y repercusión de sus páginas como, punto de vista externo, sobre las dimensiones, cambios y aportaciones de carácter político, social, cultural que han tenido lugar en todo este tiempo tan decisivo en la historia de nuestro país. Reenvío, de manera muy especial, a la revisión crítica y autocrítica llevada a cabo en el monográfico número cien, aparecido en enero de 1991, donde, por cierto, también escriben mis entrevistadores de hoy y donde yo mismo abro el tema con unas «Breves notas para la prehistoria y la intrahistoria de Sistema» que -como el resto de los trabajos- contienen datos y observaciones que pueden resultar de interés en relación con las cuestiones, más internas o más externas, aquí planteadas.

En este contexto, y puesto que se me inquiere, ¿qué decir yo personalmente, y con brevedad, acerca de la evolución de la actividad intelectual en España durante estos veinte años (1973-1993) de y desde «Sistema»? Por de pronto, aconsejar sin falta la lectura ahí de los bien documentados y construidos resúmenes y panoramas de ese tiempo, en diferentes áreas científicas y culturales, escritos por muy destacados especialistas. Me parece que, sobre estos y otros parangonables estudios, hay base para constatar en todos estos años el fortalecimiento y extensión de un pensamiento crítico y pluralista frente a la doctrina oficial de la postrera dictadura tecnocrática, con todo lo que esto implica y significa, y el paso enseguida -cabe sintetizar- desde una cultura de la oposición a una cultura de la transición, primero, y de la consolidación de la democracia, después. Ha habido, puede también decirse, a lo largo de todo este proceso un paso correlativo desde aquellas primeras actitudes intelectuales de una mayor y gran politización, preferentemente de izquierda, hacia posturas actuales más despolitizadas: algunas de estas lo son sólo para reclamar, innecesariamente, el cultivo del propio jardín (arte o ciencia), lo cual puede resultar perfectamente legítimo y eficaz; pero otras lo que expresan o encubren, es sin más una cierta, evidente, derechización del pensamiento, un conservadurismo vergonzante.

Tratando de estos temas, o de cualquiera otro, está bien evitar la «obsesión politicista», pero asimismo -yo diría- la «asepsia neoformalista» que huye como de la peste de toda, calificada de obsoleta, implicación social del pensamiento. Teorías, metodologías, filosofías, incluso meta-teorías tienen también que ver, sobre todo en este 
campo de las ciencias no naturales, con unas u otras concepciones o prácticas de la política (con mayúscula si se quiere). No me resisto en todo caso a finalizar estas observaciones sobre la España de estos años sin reenviar otra vez a mi escrito «Las ideologías de (sobre) la transición».

35. ¿Por qué los filósofos del derecho más jóvenes de tu círculo manifiestan ese desinterés por la historia del pensamiento español? No será, desde luego, porque tú no hayas insistido en ello.

O tal vez sí, tal vez sea precisamente porque yo he insistido -iy bastante!- en ello: ya se sabe, primero intentar matar al padre o luego, al menos, funcionar con su tarjeta de crédito (intelectual). Pero, si no me hacen caso, yo me resisto ser o no su padre: ni me dejo matar, ni les dejo la tarjeta sin rechistar. ¿Que se las arreglen como puedan, que ya lo hacen y bien! Además ¿por qué me preguntan a mí sobre eso los encuestadores, sobre ese «desinterés» de los «más jóvenes»? Doctores -y algunos todavía doctorandos- tiene la Santa Madre Analítica que os lo sabrán responder. Como suele contestarse en las entrevistas a ministros de quienes se inquiere por sus colegas del gobierno, es directamente a ellos a quienes habría que interrogar; y en este caso, habría a su vez, que escudriñar a fondo -¿no hay a mano algún psicoanalista argentino?- acerca de esa sospechosa fobia suya hacia la «historia del pensamiento español». ¡Vaya usted a saber lo que aparecería por ahí!

Bueno, ahora en serio (lo anterior tampoco lo es): yo creo que sigue influyendo entre no pocos hispanos el famoso complejo de inferioridad, justificado en ciertos casos por lo demás, también están las provechosas e inviolables leyes del mercado internacional y los rigorosos standards para poder llegar a ser hoy un correcto y perfecto scholar. Todo esto se refería exclusivamente -no se olvide- a nuestros jóvenes iusfilósofos. Por supuesto que los historiadores nativos y extranjeros, también algunos seniors de nuestro gremio, están desde siempre trabajando y bien (lo cual no excluye, desde luego, discrepancias) acerca de ese pensamiento contemporáneo español. Me parece, sin embargo, un grave error que las ciencias sectoriales y las filosofías especiales prescindan de ese enfoque histórico -universal $\mathrm{y}$, en este caso, local- y abandonen su sistemática investigación. Si no hacen ellos (y, tratándose de iusfilósofos, los aludidos en ese «círculo») la historia de su parcela, de su área, incluso de su propia historia, otros vendrán, de fuera o de dentro, que la harán y después, para bien (con envidia) o para mal (con furor), ya no nos podremos quejar. De todos modos, que quede bien claro -ya no tengo tiempo para batallas inútiles- que mi planteamiento es 
metodológicamente pluralista y para nada casticista ni, contra la razón, historicista o «comunitarista».

Termino este punto con un par de maldades más: una, para recordar a esos «más jóvenes» reacios a lo español que -como ocurría ante el espejo del cuento- «iya no lo son!»; aunque les parezca increíble, ya hay otros más jóvenes que ellos y, lo que es peor, a estos ya no les da repelús (ni corte) ese tipo de investigación con tesis doctorales sobre Tierno, Aranguren, Legaz, González Vicén e, incluso, gente posterior; la segunda, relativa a los encubridores y cómplices encuestadores, a quienes también acuso de un nuevo delito de hispánica ahistoricidad, al darme cuenta ahora de la no inclusión en éste, por lo demás casi exhaustivo, cuestionario de la más mínima referencia, dentro de la historia del gremio, al largo y negro capítulo de aquella serie de siniestras oposiciones universitarias que, como víctimas, yo y algunos más, tuvimos en aquellos tiempos que sufrir y soportar: significativo olvido sobre el cual, sin embargo -ya advertí que era una maldad-, no voy a admitir aquí remodelar preguntas ni para nada una nueva oportunidad, aun a costa de que ello me prive de hablar, bien, de los profesores González Vicén, Delgado Pinto y López Calera.

36. Una pregunta más personal. ¿Por qué has tendido siempre a rehusar los cargos públicos? Suponemos que el compromiso político tendría que haber implicado también que estuvieras dispuesto a asumirlos.

Pues, no; con perdón, suponen mal mis también comprometidos entrevistadores (me refiero a la segunda parte de la cuestión). El compromiso político del intelectual, tanto si se concreta o no en un partido, no tiene porqué llevarle de modo necesario a asumir, ni siquiera transitoriamente, el desempeño directo de cargos públicos; tampoco, por supuesto, a tener por fuerza que rehusarlos. Si todo intelectual con preocupación o compromiso político tuviera sin más que aceptar cargos públicos, se produciría paradójicamente la desaparición, o casi, del intelectual comprometido: lo que quedaría sería, por un lado, intelectuales no comprometidos -también en una variada gama desde la difusa politización al aparente apoliticismo- y, por otro, políticos comprometidos. Me parece, por el contrario, que tal distanciamiento, o incluso tal vacío, no es bueno y que precisamente aquel, el intelectual que mira con más atención hacia la política (en el sentido más noble y, hondo del término, como polis, ciudad, convivencia social y comunidad universal), puede, en sus diferentes graduaciones, servir como vínculo problemático de unión y conexión. Por lo demás, el tal compromiso debe ser siempre crítico, relativo y, en todo momento, revisable. 
En mi caso concreto, tal vez también influyó en esa negativa al cargo público lo que señalaba como olvido al final del punto anterior: ya se ve que no era arbitrario que lo echara de menos aquí. En el pasado tuve que dedicar no poco tiempo y esfuerzo (en esos diez años, entre 1964 y 1974) a las famosas agonísticas oposiciones para lograr un puesto de profesor en la Universidad; pero en medio hice otras cosas: libros y «conspiraciones»; fueron años, suelo así decir, de oposiciones y de oposición. Lograda al fin la cátedra, más bien tarde (a los cuarenta años), muy poco antes de la llegada de la democracia, necesitaba esa mayor estabilidad profesional, docente e investigadora, para recuperar lecturas y reorganizar mis tareas allí (cursos, tesis, etc.), así como para revisar y escribir una serie de papeles y trabajos que hasta entonces no había tenido ocasión ni tranquilidad para llevar del todo a buen término. Cuando en el 76-77 surgieron las primeras incitantes propuestas para pasar práctica y profesionalmente a la política, yo me encontraba, pues, metido de hoz y coz en aquella casi recién estrenada actividad, incrementada además con mi retorno definitivo por aquellas fechas a la Universidad Autónoma de Madrid. Luego, en el 82, ante otras muy generosas ofertas que siempre agradeceré, ya tenía plenamente decidido continuar en aquella misma universitaria dirección. De todos modos, he colaborado y ayudado lo que he podido participando, por ejemplo, en campañas electorales de amigos que así me lo pedían o en Comisiones asesoras de todo tipo (empezando por la redactora de la Constitución) y hasta fui varios meses director del «Centro de Estudios Constitucionales», donde cesé a petición propia por incompatibilidad legal (y real) con mi trabajo en la Universidad.

A pesar de todas estas anteriores «racionalizaciones», tengo en seguida que reconocer y señalar que esa mi opción fundamental no ha sido sin embargo tomada desde ningún abstracto y superior sentido del «deber» (¡como si el trabajo político fuese de menor importancia y entidad que el trabajo intelectual!) sino desde instancias más inmediatas y personales y desde condicionantes hasta más biológicos y psicológicos. O sea, que me parece que mis aptitudes, capacidades y posibilidades, mis aficiones y vocaciones (y, a su vez, las carencias de ellas o de otras), así como también el mayor entrenamiento y dedicación empleados en el pasado, van más y con mayor persistencia hacia esas tareas derivadas del estudio, la enseñanza, la escritura y la investigación. Pero, por otro lado, tampoco está tan claro que me interese sólo influir o sugerir y para nada dirigir a organizar: quizás por, eso me sentí, hace tantos años, bastante identificado con aquella tesis que aunaba entender (eso lo primero y, a su vez, después) transformar la realidad. 
37. La palabra «discípulo» tiene unas curiosas reglas de uso. En general no la utiliza el verdadero maestro. Son los que han aprendido con él los que se la atribuyen, porque son los únicos que reconocen al maestro. Pero tu caso suele ir más alla. No solo no te reconoces como maestro, sino que mantienes una relación intelectual «incesantemente crítica» con los que se consideran tus discípulos. No hay ocasión en que nos reunamos unos cuantos que no acabe en un debate teórico en el que tú pones de manifiesto tus desacuerdos. ¿Podrías explicar esta actitud intelectual?

¿Qué otra relación intelectual sino esa «incesantemente crítica», del «desacuerdo» y el «debate teórico», se puede mantener con quienes - jallá ellos!- se consideran, o no, discípulos? Sobre todo cuando tal crítica no implica, en modo alguno, desconocimiento de lo positivo y válido de sus aportaciones; más bien todo lo contrario. Ya he dicho que me gustaría haber escrito yo algunos de sus libros y artículos y saber mucho de lo que ellos saben. Lo que en el fondo creo que persigo con mi actitud no es sólo la movilización y corrección de las posiciones del interlocutor, aunque eso también, sino, de manera más inmediata, provocar su respuesta y, así, avanzar yo mismo. Trato mal a los discípulos, ya lo sé, pero es porque los considero desde el principio como mayores de edad, que lo son, también desde el punto de vista intelectual: gentes sabias y orgullosas -y, encima, jóvenescon quienes no se debe tener ninguna piedad.

$\mathrm{Me}$ parece que los mayores riesgos de esa supuesta y dinámica relación maestro-discípulo y, en definitiva, de todo grupo de trabajo son, precisamente y a la vez, la escolástica (repetición y seguidismo formal) y el autismo (incomunicación y aislamiento sectorial): para los dos, pienso que esa «incesante crítica» sea la mejor solución. De todos modos -esto lo digo absolutamente de verdad- nunca he visto ni practicado la relación intelectual como algo sólo bilateral y, menos aún, unilateralmente vertical (tampoco con los que yo considero -Bobbio, Tierno y demás- como mis propios buenos maestros), sino mucho mejor como una «totalidad» de plurales interrelaciones en una, mayor o menor, abierta comunidad: allí todo el mundo -jaunque no por igual!- tiene algo que aportar. Así, por lo menos, es como a mí me gusta funcionar y trabajar.

En realidad, todos somos discípulos -la muerte o la vejez es dejar de aprender, o de tener interés por saber- y, a la vez, irremediablemente maestros: alguien habrá, o podrá haber, que se fije en algo que uno ha dicho, hecho o escrito. Los mayores aprendemos de esos odiosos jóvenes que, como uno in illo tempore, todo lo saben y todo lo leen: y luego están, por edad, esos seres extraños, bifrontes e intermedios, como mis dos catedráticos entrevistadores, que a toda 
costa quieren prolongar su juventud atacándome a mí como maestro y echándome encima -en los dos sentidos de la expresión- a quienes en verdad (en falsedad) son ya sus propios, inevitables, discípulos. Pero todo eso, y mucho más, cabe dentro de nuestra plural y no «comunitarista» comunidad.

38. Uno de esos desacuerdos podría ser el del pensamiento anglosajón. La mayoría de tus discípulos asumimos hoy que la filosofía jurídica, moral y política anglosajona contemporánea no sólo es ineludible, sino que es el núcleo más válido de ese pensamiento. Tú, sin embargo, pareces siempre reticente ante eso. ¿Cuál es la razón?

Absolutely not! Antes de cualquier razón o explicación acerca de esas supuestas reticencias mías, que no son sino pura calumnia y difamación imagino que de algunos de mis colegas con el deliberado propósito de arruinar mi reputación dentro y fuera de la filosofía jurídica, política y moral (e incluso social) tanto a nivel nacional como internacional, quisiera hacer constar aquí, con mi total e inquebrantable adhesión, que -lo diré en la lengua del Imperio (así me entenderán allá)- my faith in North American Philosophy is, and has always been, devout and utterly unquestionable!

A su vez, tengo que hacer aquí, sin embargo, mi propia autocrítica: al menos, en tres cuestiones fundamentales. Confieso para empezar que entre esos alegados discípulos, y aunque sin atentar nunca a los serios derechos de tal supuesta «mayoría» (natural o moral), he procurado introducir y potenciar también perspectivas plurales frente a cualquier intento de monocorde absolutización, así, con la realización de tesis doctorales -sería larga la lista de sus autores- sobre filósofos alemanes, franceses, italianos, incluso latinoamericanos y -iperdóneseme!- hasta españoles: Gadamer, recuerdo, ha señalado que esto último es lo que prioritariamente nos correspondería hacer. Reconozco igualmente, en segundo lugar, que en algunos momentos he subrayado con insistencia, y con razones y documentaciones, la necesidad de no desconocer los orígenes, antecedentes, conexiones e implicaciones que tal o cual nueva tendencia o polémica del panorama norteamericano actual haya podido tener en la historia intelectual o política de estos o aquellos países europeos o de otras diferentes culturas. Finalmente, dentro de esa genérica metodología por la contextualización, también tendría que acusarme de mi propensión a no aislar el pensamiento, y la teoría, de la realidad, de la práctica política y social; pero admito que esto puede llevar a no igualar, ni confundir, desde la neutralidad formal a todas esas teorías, ni tampoco a irresponsabilizar a algunas de ellas por su relación e, incluso, coherencia 
con el conjunto de aquel «establecimiento», tanto en sus repercusiones internas como de política exterior.

Siendo esto así, ¿se me podrá disculpar que, acá o allá, de ese pensamiento anglosajón yo me haya críticamente inspirado en gentes, pongo por caso, como Russell o Keynes, Wright Mills o Chomsky, y que en filosofía ética y jurídica tenga también en cuenta a Hart, Dworkin o Rawls? Hace tiempo, yo fui durante un curso (1969-1970) profesor en la Universidad de Pittsburgh; de esos meses, y de otras más breves visitas allá, guardo recuerdos muy entrañables y esperanzados sobre personas y cosas de esa otra América común, de un pensamiento más de izquierdas que el tópico oficial, de un país más liberal y democrático de verdad.

39. Y por último, un componente evidente de tu personalidad intelectual. Tienes la misma inclinación en favor de la crítica que en contra de las rupturas. En el debate intelectual eres siempre un rival muy poco acomodaticio y muy poco incómodo. ¿De dónde viene esta rara virtud?

Contesto a esto -por ser ya la anteúltima introspección-, saludo con sincera y profunda gratitud a los eminentes doctores Laporta y Ruiz Miguel y me levanto (¿definitivamente?) del psicoanalítico y agotador diván. «En favor de la crítica, en contra de las rupturas»: me parece bien, si por ruptura se entiende violencia y agresividad, pero recuerdo que personalmente yo también rompí desde el principio con la dictadura (y sus acólitos en la Universidad) y me fui a colaborar con la democrática oposición: nada, pues, de pactos, mediación y acomodación con quienes en aquellos tiempos nos negaban, por lo demás, el pan y la sal (de la vida intelectual). Añadiré, para presumir de duro y feroz, que tampoco en la democracia me llevo con todos absolutamente bien.

También acepto -¿cómo no?- ese ingenioso y elegante juego de palabras de los entrevistadores de ser yo «un rival muy poco acomodaticio y muy poco incómodo». Que «¿de dónde viene esta rara virtud?». Esto sí que no lo sé: supongo que, como todo, de la química y de la voluntad; pero ni sé si es virtud, ni sé si aquello es del todo verdad. En no pocas ocasiones me he encontrado con que los no extremosos moderados somos en el fondo los más odiados; hay gente que se enfurece ante la contención, el matiz y la comprensión: «esos son los peores», se les oye con frecuencia gritar. Pero yo, desde luego, no me encuentro nada cómodo ni feliz ante esa, a veces, insospechada enemistad que ahora o explota cuando uno menos se lo espera.

En un plano por fortuna mucho menos dramático, ahora sé, por ejemplo, que algunos colegas iusfilósofos están incomodados o enfadados 
conmigo por un papel, un folio no más, que escribí y difundí internamente entre gentes del gremio hace algún tiempo y en el que (medio en broma, medio en serio) sintetizaba y diferenciaba una serie de tendencias teórico-políticas en el seno de la Filosofía del Derecho española actual. Cómo circularon versiones apócrifas y con adscripción de nombres propios -cosa que yo nunca hice-, cómo además ya se ha aludido a él de forma simpática pero maniquea en un libro serio, con introducción irreflexiva, del amigo Luis García San Miguel, creo que lo mejor es aprovechar estas contestaciones informales para darlo a la imprenta por primera vez. Las tales escuelas y tendencias, a las que se ha incorporado alguna pequeña modificación a la primera versión -así la apertura del grupo cuatro en el que, constato, casi todos se quieren meter- e, insisto, sin pretender a nadie etiquetar ni ofender, eran, son, las que van recogidas en el cuadro que figura al final de estas contestaciones, en página especial (no se olvide, por favor, el componente lúdico que, espero, los graves y severos iusfilósofos me sabrán perdonar).

40. Una última pregunta. La puedes tomar a beneficio de inventario. ¿Que es hoy ser de izquierdas?

¿Cómo qué «a beneficio de inventario»? ¿Para qué, entonces, todo lo anterior? Tampoco pretendo escindir y repartir el mundo en dos, derechas e izquierdas, de manera esencialista, binaria y maniquea: malos y buenos, absolutamente incomunicados entre sí, inconfundibles -como ocurría antes con los arquetipos del «rojo» y el «carca»- al primer golpe de vista. Todas estas calificaciones se dan siempre dentro de un proceso histórico-real incluso de expresión cuantitativa pero no inamovible ni unidimensional. En nuestros días los conflictos sociales se han hecho más complejos, no encierran sólo diferencias económicas y de clase sino también de etnias, de sexo, de edad, de cultura, de minorías marginadas por otras muy diversas, y hasta opuestas, sinrazones. Por otro lado, en ciertas áreas geográficas (España, incluida) algunos de esos conflictos tradicionales han visto reducidas sus distancias, sus tensiones y su dramatismo, aunque otros más o menos nuevos enfrentamientos hayan aparecido o reforzado su presencia.

Todo es hoy más difícil, mucho más difícil. Pero nada de eso autoriza el simplismo de unir, fundir y confundir a la derecha y a la izquierda, a las filosofías reaccionarias (ni a las conservadoras), más defensoras de viejos órdenes, con las filosofías de la razón crítica, más impulsoras de los derechos humanos -libertad, igualdad, solidaridad- y de las éticas laicas, más identificadas con los avances científicos y las propuestas de transformación social. Y lo mismo, mutatis 
mutandis, ocurre con la política. Por lo general es la derecha quien niega la diferencia, quien tiene más interés en indefinir, ocultar y contaminar tales plurales y graduales dimensiones, quien se empecina, en definitiva, en hacer creer que ya no existen derechas e izquierdas. Pero, a pesar de aquellas mayores dificultades actuales para diferenciar, a pesar del «achique de espacios», e incluso, en los últimos tiempos, de una cierta derechización de la izquierda, sigue siendo verdad que no todo es igual, desde luego, ni todo vale por igual: aunque repito que habrá siempre que esforzarse por la no demonización de lo ajeno ni la deificación de lo propio. Las menores o aparentes pequeñas diferencias pueden ser, de hecho son, en muchos casos, absolutamente decisivas (small is beautifull). Hay y debe haber, también, diferencias en el enfoque de la economía y de la macroeconomía a escala mundial entre las políticas de la izquierda y de la derecha, como -en un plano tal vez más inmediatolas hay y debe haberlas, sin duda, ante problemas sociales, culturales, de libertades personales que son de la máxima importancia hoy para una convivencia plural, laica, con respeto a las minorías, con solidaridad e igual atención a las necesidades básicas y a los derechos fundamentales de todos.

Derechas e izquierdas fue el título precisamente de un artículo mío publicado en el diario «El Sol» de Madrid en abril de 1991, artículo que por cierto ha tenido el muy alto honor de ser citado y resumido por Norberto Bobbio en su último libro Destra e sinistra. Ragioni e significati di una distinzione politica. Allí, en aquel escrito, complementando cosas similares a las aquí resumidas, venía a indicar yo -con talante, creo, bastante realista y moderado- algunas no fijas ni exhaustivas señas de identidad de la izquierda que, revisadas, quizás valga la pena volver ahora a reconsiderar: así entre otras -comenzando por las que derivan de la «participación en los resultados»-, una mayor predisposición para políticas económicas redistributivas y de nivelación proporcional, basadas más -y más de lo que ha sido habitual- en el trabajo que en el capital; de modo similar, un mayor aprecio en la organización social hacia lo público y común y no sólo, egoísta o elitistamente, hacia lo privado e individual; más alta prevalencia de los valores de cooperación y colaboración sobre los de confrontación y competición, sin negar tampoco a éstos su legitimidad; más atención al diálogo con los sindicatos y los nuevos movimientos sociales, éstos con sus demandas ecologistas, pacifistas, feministas, antirracistas, etcétera; preocupación por la efectiva realización, y no la sola declaración, de los derechos humanos, muy en especial de grupos marginados y más desfavorecidos, infancia, tercera edad, inmigrantes, etcétera; insistencia en la prioridad de dar cumplida satisfacción para todos a necesidades básicas como son las 
de buena sanidad, escuela, vivienda, trabajo, jubilación, etcétera; mayor sensibilidad y amistad internacional hacia los pueblos de las áreas pobres, dependientes y deprimidas; autonomía de la libre voluntad y del debate racional -pasando ya a la «participación en las decisiones»- tanto para establecer políticas mayoritarias y democráticas como para construir éticas críticas y en transformación, no impuestas por argumentos de autoridad o por dogmas de organizaciones religiosas dotadas además de un carácter carismático y/o tradicional. Como se ve, igual libertad y liberación real.

Alguien, sin duda, me discutirá o me negará que esa sea la izquierda «de verdad». Antonio García Santesmases -espero- me defenderá. En cualquier caso, yo no he pretendido el monopolio de tal verdad, ni siquiera el copyright de originalidad, al enunciar ahora estas plurales y revisables señas de identidad. Lo que quería era más bien poder contribuir con alguna idea o aportación válida al debate abierto precisamente en el seno hoy de tal izquierda. Yo veo a ésta -ya se habló de ello aquí con anterioridad- como síntesis constructiva de la socialdemocracia, y su trabajo en las instituciones del Estado social y democrático de Derecho, con las mejores aportaciones libertarias, en nuestros días representadas por esos nuevos movimientos sociales y sus demandas de fondo para una mayor, real, autonomía moral, universal, contando con el entorno físico, material, y con la libre ilustrada autodeterminación personal. De esa izquierda es de la que he dicho -y así lo creo- que tiene más futuro que pasado (con ser éste ya muy importante), que, contra el tópico de moda, aquella posee en definitiva mucho más potencial, teórico y práctico, que la derecha para afrontar con buen futuro, justo y eficaz, los problemas planteados en el mundo actual. Por ahí, al menos, es por donde yo querría poder seguir trabajando algunos, muchos, años más. 
UNA CLASIFICACIÓN DESENFADADA DE LA FILOSOFÍA

DEL DERECHO EN ESPAÑA: ESCUELAS Y TENDENCIAS

\begin{tabular}{|c|c|c|c|}
\hline $\begin{array}{c}\text { Denominación de } \\
\text { origen }\end{array}$ & Son/representan & $\begin{array}{c}\text { Línea } \\
\text { ideológico-política }\end{array}$ & Sede social \\
\hline 1. Tiranía y Cía. & La reacción & $\begin{array}{l}\text { Tradicionalismo/ } \\
\text { Totalitarismo }\end{array}$ & El Pardo \\
\hline 2. Opus /Opas & El dogma & Conservadores & $\begin{array}{l}\text { Vaticano } 1 .^{\circ} \text { (y Camino de } \\
\text { Torreciudad) }\end{array}$ \\
\hline 3. Moros y cristianos & La ley natural & $\begin{array}{l}\text { Democracia- } \\
\text { cristiana }\end{array}$ & Vaticano $2 .^{\circ}$ derecha \\
\hline 4. Raros e irreales & $\begin{array}{l}\text { El caos } \\
\text { (dentro del orden) }\end{array}$ & Apolíticos (Dícense) & Doquier Quartier \\
\hline 5. Doxa-Tossa & $\begin{array}{l}\text { El mercado } \\
\text { (y su análisis) }\end{array}$ & Liberales (plurales) & $\begin{array}{l}\text { Tossa de Mar: Apartamentos } \\
\text { «Prima Facie» (muy bien } \\
\text { amueblados) }\end{array}$ \\
\hline 6. Sistema (abierto) & $\begin{array}{l}\text { El Estado } \\
\text { (y su crítica) }\end{array}$ & Social-demócratas & $\begin{array}{l}\text { Suresnes (Villa «El olmo } \\
\text { viejo») }\end{array}$ \\
\hline $\begin{array}{l}\text { 7. Mientras } \\
\text { tanto/Entresueños }\end{array}$ & $\begin{array}{l}\text { Los movimientos } \\
\text { sociales } \\
\text { (y su dialéctica) }\end{array}$ & $\begin{array}{l}\text { Marxistas/Libertario } \\
\mathrm{s}\end{array}$ & Paseo de las Acracias, s/n. \\
\hline
\end{tabular}


